OPEN ACCESS

Edited by:

Krystyna Pierzchala-Koziec,

University of Agriculture in Krakow,

Poland

Reviewed by:

Marek Skrzypski,

Poznań University of Life Sciences,

Poland

Maciej Sassek,

Poznań University of Life Sciences,

Poland

*Correspondence:

Huijuan Zhu

shengxin2004@163.com

Fengying Gong

fygong@aliyun.com:

fygong@sina.com

Specialty section:

This article was submitted to Lipid and Fatty Acid Research,

a section of the journal

Frontiers in Physiology

Received: 15 May 2019 Accepted: 27 September 2019

Published: 11 October 2019

Citation:

Miao $H$, Pan $H$, Wang L, Yang $H$, Zhu H and Gong F (2019) Ghrelin Promotes Proliferation and Inhibits Differentiation of 3T3-L1 and Human

Primary Preadipocytes.

Front. Physiol. 10:1296.

doi: 10.3389/fphys.2019.01296

\section{Ghrelin Promotes Proliferation and Inhibits Differentiation of 3T3-L1 and Human Primary Preadipocytes}

\author{
Hui Miao, Hui Pan, Linjie Wang, Hongbo Yang, Huijuan Zhu* and Fengying Gong* \\ Key Laboratory of Endocrinology of National Health Commission, Department of Endocrinology, Peking Union Medical \\ College Hospital, Chinese Academy of Medical Sciences and Peking Union Medical College, Beijing, China
}

Objective: Ghrelin is a 28-amino-acid peptide that regulates energy hemostasis, glucose and lipid metabolism. We aimed to explore the effects of ghrelin on the proliferation and differentiation of 3T3-L1 and human primary preadipocytes.

Methods: 3-(4,5-Dimethylthiazol-2-yl) 2,5-diphenyl tetrazolium bromide (MTT) spectrophotometry, Oil Red $\mathrm{O}$ staining, intracellular glycerol-3-phosphate dehydrogenase (G-3-PDH) assays and semiquantitative reverse transcription polymerase chain reaction were used to investigate the action of ghrelin.

Results: Ghrelin (0.01-1000 ng/ml) significantly increased the numbers of 3T3-L1 cells, and the maximum stimulatory effect was observed with the $10 \mathrm{ng} / \mathrm{ml}$ ghrelin treatment for $24 \mathrm{~h}(p<0.05)$. Ghrelin also promoted the proliferation of human primary preadipocytes from $24 \mathrm{~h}(p<0.05)$ to $48 \mathrm{~h}(p<0.05)$ at a concentration of $1000 \mathrm{ng} / \mathrm{ml}$. Further investigation showed that IGF-1 levels were notably increased in ghrelin-treated 3T3-L1 and human preadipocytes, and IGF-1 antibody was capable to attenuate this stimulatory action of ghrelin (all $p<0.05$ ). Additionally, ghrelin significantly suppressed the differentiation of 3T3-L1 and human primary preadipocytes; $10 \mathrm{ng} / \mathrm{ml}$ ghrelin notably downregulated G-3-PDH activities in 3T3-L1 cells on day 3 and in human cells from days 4 to 12 following differentiation (all $p<0.05$ ), and the intracellular lipoprotein lipase mRNA levels were lower than that of the controls $(p<0.05)$. Further investigation showed that the mRNA levels of peroxisome proliferator-activated receptor $\gamma 2$ (PPAR $\gamma 2$ ) and CCAAT/enhancer binding protein $\alpha$ (C/EBPs) were also suppressed in ghrelin-treated human differentiating adipocytes.

Conclusion: Ghrelin promotes the proliferation of 3T3-L1 and human primary preadipocytes by increasing the expression of IGF-1. Ghrelin inhibits murine and human adipocyte differentiation by downregulating PPAR 2 and C/EBP $\alpha$ levels, consequently leading to decreased lipid accumulation and lipogenic enzymes expression.

Keywords: ghrelin, proliferation, differentiation, 3T3-L1 preadipocytes, human primary preadipocytes 


\section{INTRODUCTION}

Obesity and its related disorders, such as type 2 diabetes, dyslipidemia, and cardiovascular disease has increased in prevalence in recent years and has become a vital health concern worldwide (Corica et al., 2015; Martin et al., 2015). Obesity is mainly due to excessive energy intake and less expenditure, thereby leading to accumulation of fat (Wright and Aronne, 2012), but the mechanism of obesity has not been fully elucidated. It has been reported that increased adipocyte number (hyperplastic growth) and adipocyte volume (hypertrophic growth) are of great importance in the occurrence and development of obesity (Berry et al., 2014).

Preadipocytes are recruited from multipotent stem cells and regularly undergo mitotic clonal expansion, thereby upregulating adipocyte number. When treated with appropriate cytokines or hormones, preadipocytes are growth-arrested and induced to differentiate (Young et al., 1995; Lane and Tang, 2005). In the process of differentiation, some transcription factors have been reported to activate adipogenesis. Two known factors are peroxisome proliferator-activated receptor $\gamma_{2}(\operatorname{PPAR} \gamma 2)$ and CCAAT/enhancer binding protein $\alpha$ (C/EBPs), which cooperate as a complex to promote preadipocyte differentiation and are required for the maintenance of adipocytes (Rosen et al., 2002; Imai et al., 2004). Moreover, these transcription factors are associated with activating the expression of adipocytespecific enzymes, which are associated with lipogenesis and lipid retention. For instance, lipoprotein lipase (LPL) reveals lipid storage in the early stages of differentiation, whereas fatty acid synthase (FAS), acetyl-CoA carboxylase (ACC), and glycerol-3phosphate dehydrogenase (G-3-PDH) are involved in triglyceride metabolism in late stages (Ailhaud, 1996; Lenhard, 2011; Mracek et al., 2013; Kersten, 2014).

Factors influencing adipogenesis and lipid retention have been receiving substantial attention from researchers, and several hormones, such as insulin, glucocorticoid and thyroxine, have been found to affect proliferation and differentiation of preadipocytes (Geloen et al., 1989; Obregon, 2008). Ghrelin, a 28-amino-acid peptide mainly secreted by the gastric fundus mucosa, was first described in 1999 and is the endogenous ligand of the growth hormone secretagogue receptor la (GHS-R1a) (Kojima et al., 1999). Ghrelin stimulates appetite and food intake by activating Neuropeptide Y (NPY) neurons and agouti-related peptides (AGRP) in the hypothalamus (Warchol et al., 2014), and a negative association of ghrelin and body mass index (BMI) has been found in both rats and human (Tschop et al., 2001; Williams et al., 2006). Recent studies have also found that ghrelin functions directly in adipocytes. Ghrelin stimulates adipogenesis of mature rat adipocytes from perigonadal, epididymal and parametrial regions, mainly by increasing adipogenic factors and lipogenic enzymes (Choi et al., 2003; Porteiro et al., 2013). It also suppresses lipolysis in rat visceral adipocytes through the activation of phosphoinositide 3-kinase (PI3K) (Baragli et al., 2011).

Several studies have shown that ghrelin stimulates the adipogenesis of 3T3-L1 preadipocytes (Choi et al., 2003; Churm et al., 2017), but the detailed mechanism of ghrelin has not been fully clarified. Insulin-like growth factor-1 (IGF-1) is a protein secreted by the liver after stimulation from growth hormone (GH), and the GH/IGF-1 axis mediates mitogenic and functional activities in cells throughout the body (Ashpole et al., 2015). The IGF-1 signal activates the phosphatidylinositol 3kinase (PI3K)/Akt and extracellular regulated protein kinases $(\mathrm{ERK}) /$ mitogen-activated protein kinase (MAPK) pathways, thereby regulating cellular proliferation and differentiation (Kasprzak and Adamek, 2012; Gao et al., 2013; Ye et al., 2018). Ghrelin has been shown to promote the growth and differentiation of adipocytes via the MAPK and PI3K/Akt pathways (Kim et al., 2004; Liu et al., 2015), but whether this effect is achieved through insulin-like growth factor 1 (IGF-1) is not clear. Additionally, most studies have focused on mouse cells, but according to our knowledge, few studies have illustrated the regulatory effect of ghrelin on human preadipocytes. Therefore, the purpose of our study was to determine the effect of ghrelin on the proliferation and differentiation of mouse 3T3-L1 and human primary preadipocytes.

\section{MATERIALS AND METHODS}

\section{Materials}

3T3-L1 preadipocytes were received as a kind gift from the Department of Genetics, Institute of Life Sciences, Peking University, Beijing. Human primary preadipocytes were obtained from the abdominal subcutaneous adipose tissues (SATs) of three patients undergoing surgery (appendicitis, cholelithiasis, and colon benign neoplasm). The clinical details of these three patients are listed in Supplementary Table S1. The study was approved by the ethics committee of Peking Union Medical College Hospital (No. JS-1093). All patients provided informed consent before adipose tissue was obtained during the surgery. Rat ghrelin was purchased from Sigma, United States. Human IGF-1 and IGF-1 antibodies were kind gifts from WHO and NIDDK, NIH, United States, respectively. Trizol RNA kit was purchased from Promega, United States. Ultraviolet-visible spectrophotometer was purchased from Hitachi, Japan. Applied Biosystems PCR System was purchased from Promega, United States.

\section{Cell Culture and Differentiation of 3T3-L1 and Human Primary Preadipocytes}

Human subcutaneous adipose tissues were prepared in 5$10 \mathrm{~g}$ samples, then rinsed by $1 \times$ phosphate buffered saline (PBS) three times. The remaining connective tissue and blood vessels were cleared. The adipose tissues were digested with $5 \mathrm{ml}$ collagenase $(2 \mathrm{mg} / \mathrm{ml})$ for $40 \mathrm{~min}$ at $37^{\circ} \mathrm{C}$. Samples were filtered through a $25 \mu \mathrm{m}$ mesh and centrifuged at $600 \mathrm{~g}$ for $5 \mathrm{~min}$. The supernatant was discarded, and the cell pellet was re-suspended in DMEM/F12 medium. Unfiltered tissues were digested once more according to the steps above. Cells were collected and counted before being seeded in DMEM/F12 (HyClone, United States) with the addition of 10\% FBS (Yuan Heng Sheng Ma Biotechnology Research Institute, China), then cultured in a $5 \% \mathrm{CO}_{2} 95 \%$ air atmosphere incubator. The inverted phase contrast microscope (Olympus, Japan) was used to observe 
the growth and differentiation state. The cells were induced to differentiate in AIM-V (Gibco, United States) medium supplemented with $0.5 \mu \mathrm{M}$ insulin, $0.25 \mu \mathrm{M}$ dexamethasone, $0.2 \mathrm{nM}$ thyroxine, and $0.5 \mathrm{nM} 3$-isobutyl-1-methylxanthine (IBMX) (Sigma, United States). The differentiation medium was refreshed every 2 days.

\section{Proliferation of 3T3-L1 and Human Primary Preadipocytes}

Preadipocytes were seeded in a 96-well plate with a density of $5 \times 10^{3} /$ well in $10 \%$ FBS/DMEM medium for $12 \mathrm{~h}$, then transferred to AIM-V medium. After 4 days, 3T3-L1 preadipocytes were added with $0.01,0.1,1,10,100,1000 \mathrm{ng} / \mathrm{ml}$ ghrelin, and human cells were added with $0.1,10,1000 \mathrm{ng} / \mathrm{ml}$ ghrelin. After 4, 8, 24, 48 and $72 \mathrm{~h}$, the preadipocytes were rinsed twice using $1 \times$ phosphate buffered saline (PBS). 3-(4,5dimethylthiazol-2-yl) 2,5-diphenyl tetrazolium bromide (MTT, Sigma, United States) solution was added to each well with a final concentration of $1 \mathrm{mg} / \mathrm{mL}$, and the cells were incubated for $4 \mathrm{~h}$. Then, $100 \mu \mathrm{L}$ dimethylsulfoxide solution was added, and the cells were shaken for $10 \mathrm{~min}$. Afterward, optical density (OD) value was recorded using an ELISA reader (Anthos Labtec, Austria) at a wavelength of $492 \mathrm{~nm}$. IGF-1 antibody was added after treatment with ghrelin (10 and $1000 \mathrm{ng} / \mathrm{ml}$ in rat and human cells, respectively). Experiments were repeated six times with individual octuplicate samples in each experiment.

3T3-L1 preadipocytes were seeded in a 96-well plate with a density of $8 \times 10^{3} /$ well in $10 \% \mathrm{FBS} / \mathrm{DMEM}$ medium for $12 \mathrm{~h}$. The cells were rinsed twice using $1 \times$ phosphate buffered saline (PBS), then transferred to X-Vivo 15 medium (Lonza, United States) medium for 4 days. After treatment with 1, 10, and $100 \mathrm{ng} / \mathrm{ml}$ ghrelin for 24 and 48 h, $10 \mu \mathrm{L}$ of the Cell Counting Kit-8 (CCK-8, Sagecreation, Beijing) solution was added to each well of the plate. The cells were then incubated for $2 \mathrm{~h}$ in the incubator, and the absorbance was measured at 450 and $620 \mathrm{~nm}$ using a microplate reader (Thermo, United States).

3T3-L1 and human preadipocytes were seeded at a density of $5 \times 10^{3} /$ well as mentioned above. After 4 days, 3T3-L1 preadipocytes were added with $0.25,1,2.5,5,10,25$, and $100 \mathrm{ng} / \mathrm{ml} \mathrm{IGF-1,} \mathrm{and} \mathrm{human} \mathrm{primary} \mathrm{preadipocytes} \mathrm{were} \mathrm{added}$ with 1, 10, $100 \mathrm{ng} / \mathrm{ml} \mathrm{IGF-1} \mathrm{for.} \mathrm{After} 24 \mathrm{~h}$, MTT assays were conducted to determine the effect of IGF-1 on proliferation.

\section{Differentiation of 3T3-L1 and Human Primary Preadipocytes}

3T3-L1 and human preadipocytes were seeded at a density of $5 \times 10^{3} /$ well in 96 -well plate and the differentiation was performed based on the protocol mentioned above. After 3 days in AIM-V medium, cells were treated with $0.1,10,1000 \mathrm{ng} / \mathrm{ml}$ ghrelin and 1, 10, $100 \mathrm{ng} / \mathrm{ml}$ IGF-1 in AIM-V differential medium for 4, 8, 12 days for human primary preadipocytes and 1, 3, 6 days for 3T3-L1 cells due to a faster differentiation rate in murine preadipocytes. Oil Red O (Ameresco, United States) staining was conducted as described previously (Zhu et al., 2006). In brief, preadipocytes were washed twice using $1 \times$ PBS, following treatment with $10 \%$ fresh formaldehyde for $1 \mathrm{~h}$ at room temperature for fixation, and then, the cells were stained with
$0.6 \%(\mathrm{w} / \mathrm{v})$ filtered Oil red $\mathrm{O}$ solution for $2 \mathrm{~h}$ and photographed using an inverted phase contrast microscope. $100 \mu \mathrm{L}$ isopropanol was added to dissolve oil red $\mathrm{O}$ dyes, and the OD value was measured using an ELISA reader at a wavelength of $492 \mathrm{~nm}$. Experiments were repeated six times with octuplicate samples in each experiment.

Enzyme G-3-PDH is specifically expressed in differentiating adipocytes, so the activity of Glycerol-3-phosphate dehydrogenase (G-3-PDH) was measured to observe the triglyceride synthesis action of cells (Rauchová et al., 2004). Murine and human cells were treated with $10 \mathrm{ng} / \mathrm{ml}$ ghrelin and IGF-1 for the indicated time, then washed twice using $1 \times$ PBS, and $0.5 \mathrm{ml}$ of lysis buffer $(50 \mathrm{mM}$ Tris, $1 \mathrm{mM}$ EDTA, $0.1 \mathrm{mM} \beta$-mercaptoethanol) was added to each well. Subsequently, the cells were scraped and sonicated in ice for $30 \mathrm{~s}$ to generate cell lysis. $300 \mu \mathrm{L}$ samples was transferred to $1.5 \mathrm{ml}$ assay buffer (100 mM Triethanolamine hydrochloride, $2.5 \mathrm{mM}$ EDTA, $0.12 \mathrm{mM} \mathrm{NADH}, 0.1 \mathrm{mM} \beta$-mercaptoethanol) to detect G-3-PDH activity. G-3-PDH activity was tested using an ultraviolet spectrophotometer at a wavelength of $340 \mathrm{~nm}$. $100 \mu \mathrm{L}$ dihydroxyacetone phosphate buffer was added and activity was remeasured at $340 \mathrm{~nm}$. 1 unit of G-3-PDH activity represents the oxidation amount of $1.0 \mathrm{nM} \mathrm{NADH}$ per minute. Experiments were replicated three times with triplicate samples in each experiment.

\section{Semiquantitative Reverse Transcription-PCR (RT-PCR) Analysis}

The differentiating cells were treated with $10 \mathrm{ng} / \mathrm{ml}$ ghrelin and IGF-1 for 8 days. Total RNA was extracted using a Trizol RNA kit (Promega, United States), and $2 \mu \mathrm{g}$ RNA was reverse transcribed with an RT-PCR system including M-Mul reverse transcriptase (Promega, United States), RNasin (Promega, United States), Oligo (dT) primer (Promega, United States) and deoxyribonucleoside Triphosphate (TaKaRa, Japan). $2 \mu \mathrm{l}$ RT products (cDNA) were amplified with human LPL, PPAR $\gamma 2$, $\mathrm{C} / \mathrm{EBP} \alpha, \beta$-actin primers and mouse LPL, IGF-1 primers as shown in Table 1. $10 \mu$ l RT-PCR products were electrophoresed in $2 \%$ agarose gel in Tris-acetate-EDTA buffer. The gel was

TABLE 1 | Primers used in RT-PCR.

\begin{tabular}{|c|c|c|}
\hline Genes & Primers & Length (bp) \\
\hline hLPL & $\begin{array}{l}\text { 5'-ACA CAG CTG AGG ACA CTT GC-3' } \\
\text { 5'-CAC TGG GTA ATG CTC CTG AG-3' }\end{array}$ & 227 \\
\hline hPPAR $\gamma 2$ & $\begin{array}{l}\text { 5'-GAT ACA CTG TCT GCA AAC ATA TCA CAA-3' } \\
5^{\prime \prime} \text {-CCA CGG AGC TGA TCC CAA-3' }\end{array}$ & 91 \\
\hline $\mathrm{hC} / \mathrm{EBP} \alpha$ & $\begin{array}{l}\text { 5'-GCA AGG CCA AGA AGT CGG TGG AC-3' } \\
5^{\prime} \text {-TGC CCA TGG CCT TGA CCA AGG AG-3' }\end{array}$ & 252 \\
\hline$\beta$-Actin (human) & $\begin{array}{l}\text { 5'-GTG GGG CGC CCC AGG CAC CA-3' } \\
\text { 5'-CTT CCT TAA TGT CAC GCA CGA TाT C-3' }\end{array}$ & 540 \\
\hline $\mathrm{mLPL}$ & $\begin{array}{l}\text { 5'-ATG GAG AGC AAA GCC CTG C-3' } \\
5^{\prime} \text {-AGT CCT CTC TCT GCA ATC AC-3' }\end{array}$ & 770 \\
\hline mlGF-1 & $\begin{array}{l}\text { 5'-ATG GGG AAA ATC AGC AGT C-3' } \\
5^{\prime} \text {-AGG TCT TGT TTC CTG CAC-3' }\end{array}$ & 413 \\
\hline mGAPDH & $\begin{array}{l}\text { 5'-TCC ACT CAC GGC AAA TTC AAC G-3' } \\
5^{\prime} \text {-TAG ACT CCA CGA CAT ACT CAG C-3' }\end{array}$ & 145 \\
\hline
\end{tabular}


then stained with ethidium bromide and photographed using an Alphalmager M2200 (AlphaInnotech, United States). Expression changes were determined by the density ratio of the target genes to mGAPDH or $\beta$-actin in 3T3-L1 and human primary preadipocytes, respectively. Experiments were replicated three times with triplicate samples in each experiment.

\section{Quantitative Real-Time RT-PCR (qRT-PCR) Analysis}

3T3-L1 preadipocytes were cultured in X-Vivo 15 medium and MesenCult ${ }^{\mathrm{TM}}$-ACF Plus Medium (STEMCELL, Canada) based on the protocol mentioned above. Concentrations of 1, 10, and $100 \mathrm{ng} / \mathrm{ml}$ ghrelin (abcam, United Kingdom, ab120231) were administrated for $24 \mathrm{~h}$ to preadipocytes and 8 days to differentiating cells. RT-qPCR analysis was performed using SYBR Premix Ex Taq (TaKaRa, Japan) and an ABI7500 PCR system (Applied Biosystems, San Francisco, CA, United States) as previously described (Yan et al., 2017). The total RNA was extracted using an EZNA total RNA kit (Omega Biotek, United States, Lot R6834-01). $1 \mu \mathrm{g}$ RNA was reverse transcribed to cDNA using the PrimeScript ${ }^{\text {TM }}$ RT reagent Kit (TaKaRa, Japan). RT-qPCR was conducted in 3T3-L1 preadipocytes and adipocytes to assess the expression of proliferation and differentiation-related genes. The primer sequences of target genes are listed in Table 2. PPIA was used as the internal control, and the relative expression of each target gene was calculated using the formula $2^{-\Delta \Delta \mathrm{Ct}}$. RT-qPCR was duplicated in 2 wells in a final volume of $20 \mu \mathrm{L}$.

\section{Statistical Analysis}

All statistical analyses were performed using SPSS 10.0 for Windows, and all values were expressed as the mean \pm standard deviation (SD). A $t$-test was used to analyze for two groups, and

TABLE 2 | Primers used in qRT-PCR.

\begin{tabular}{|c|c|c|}
\hline Genes & Primers & Length (b \\
\hline mPPIA & $\begin{array}{l}5^{\prime} \text {-GCTGGACCAAACACAAACGG-3' } \\
5^{\prime} \text {-TCCTGGACCCAAAACGCTC-3' }\end{array}$ & 139 \\
\hline mcyclin D1 & $\begin{array}{l}\text { 5'-GCGTACCCTGACACCAATCTC-3' } \\
\text { 5'-CTCCTCTTCGCACTTCTGCTC-3' }\end{array}$ & 183 \\
\hline mcyclin E1 & $\begin{array}{l}\text { 5'-GTGGCTCCGACCTTTCAGTC-3' } \\
\text { 5'-CACAGTCTTGTCAATCTTGGCA-3' }\end{array}$ & 101 \\
\hline mcyclin B2 & $\begin{array}{l}\text { 5'-GCCAAGAGCCATGTGACTATC-3' } \\
\text { 5'-CAGAGCTGGTACTITGGTGTC-3' }\end{array}$ & 114 \\
\hline $\operatorname{mBAX}$ & $\begin{array}{l}\text { 5'-TGAAGACAGGGGCCTाITTG-3' } \\
\text { 5'-AATTCGCCGGAGACACTCG-3' }\end{array}$ & 140 \\
\hline $\mathrm{mBcl}-2$ & $\begin{array}{l}\text { 5'-GCAGAGATGTCCAGTCAGC-3' } \\
5^{\prime} \text {-CCCACCGAACTCAAAGAAGG-3' }\end{array}$ & 129 \\
\hline$m B c l-x L$ & $\begin{array}{l}\text { 5'-GGTATTGGTGAGTCGGATTGC-3' } \\
\text { 5'-CGGCTCTCGGCTGCTG-3' }\end{array}$ & 132 \\
\hline mPPAR $\gamma 2$ & $\begin{array}{l}5^{\prime} \text {-GCAGGAGCAGAGCAAAGAG- } 3^{\prime} \\
5^{\prime} \text {-GGACACCATACTTGAGCAGAG-3' }\end{array}$ & 158 \\
\hline $\mathrm{mC} / \mathrm{EBP} \alpha$ & $\begin{array}{l}5^{\prime} \text {-CAAGAACAGCAACGAGTACCG-3' } \\
5^{\prime} \text {-GTCACTGGTCAACTCCAGCAC-3' }\end{array}$ & 124 \\
\hline $\mathrm{mLPL}$ & $\begin{array}{l}\text { 5'-GCCTGAGTTGTAGAAAGAATCG-3' } \\
\text { 5'-GTTGTGTTGCTTGCCATCC-3' }\end{array}$ & 173 \\
\hline mACC & $\begin{array}{l}\text { 5'-CAGCATCTCTAACTTCCTTCAC-3' } \\
\text { 5'-CGAGCCATTCATTATCACTACG-3' }\end{array}$ & 163 \\
\hline
\end{tabular}

one-way ANOVA was used for three or more groups. The MannWhitney $U$ or Kruskal-Wallis test was used if data were still not normally distributed. $p<0.05$ was considered significant for all analyses.

\section{RESULTS}

\section{Morphological Features of 3T3-L1 Preadipocytes and Human Primary Preadipocytes}

3T3-L1 cells (Figure 1A) were fusiform or had multiple protrusions, with round nucleus in the center of the cytoplasm. On day 4 following differentiation (Figure 1B), small lipid droplets could be observed in the cytoplasm. With longer differentiation periods, the number of the lipid droplets increased, small lipid droplets merged into large lipid droplets and the cells became oval or circular. On the $14^{\text {th }}$ day of differentiation, large lipid droplets could be notably observed, and 95 to $98 \%$ of the cells differentiated to mature adipocytes (Figure 1C). As shown in Figure 1D, the morphology of human primary preadipocytes was similar to murine cells. On the $10^{\text {th }}$ day of differentiation, lipid droplets became larger and pushed the nucleus to one side of the cell (Figure 1E). As depicted in Figure 1F, more than $80 \%$ of the human cells accumulated lipid droplets in the cytoplasm.

\section{Ghrelin and IGF-1 Stimulated the Proliferation of Mouse 3T3-L1 Preadipocytes and Human Primary Preadipocytes}

3T3-L1 preadipocytes were treated with $0.01-1000 \mathrm{ng} / \mathrm{ml}$ ghrelin for $24 \mathrm{~h}$. As presented in Figure 2A, $0.01 \mathrm{ng} / \mathrm{ml}$ ghrelin significantly promoted cell growth compared with the control group $(107.7 \pm 4.2$ vs. $100.0 \pm 5.9, p<0.05)$, and this effect was further enhanced with the increase in ghrelin concentrations. The maximum promotion effect was observed at $10 \mathrm{ng} / \mathrm{ml}$, which was up to $114.9 \%$ of the control group $(p<0.05)$. When the concentration of ghrelin was increased to 100 and $1000 \mathrm{ng} / \mathrm{ml}$, its promotional effect was slightly weakened but was still higher than that of the control groups $(p<0.05)$.

To investigate the time curve of ghrelin on 3T3-L1 preadipocyte proliferation, 3T3-L1 preadipocytes were treated with $10 \mathrm{ng} / \mathrm{ml}$ ghrelin for 4-48 h. As shown in Figure 2B, the OD value of the control groups gradually increased during the 4-48 h period, which indicated the appropriate growth of 3T3L1 cells. After treating these cells with ghrelin, the OD values of the cells also gradually increased and were consistently higher than that of the controls from 4 to $48 \mathrm{~h}$, but the significant stimulatory effect was only observed at $24 \mathrm{~h}$ (149.4 \pm 4.6 vs. $134.2 \pm 6.1 \%, p<0.05)$.

We observed that ghrelin promoted the proliferation of 3T3-L1 preadipocytes, and a similar result was also noted in human primary preadipocytes. Human primary preadipocytes were treated with $0.1-1000 \mathrm{ng} / \mathrm{ml}$ ghrelin for $24 \mathrm{~h}$. As shown in Figure 2C, only $1000 \mathrm{ng} / \mathrm{ml}$ ghrelin slightly but significantly 


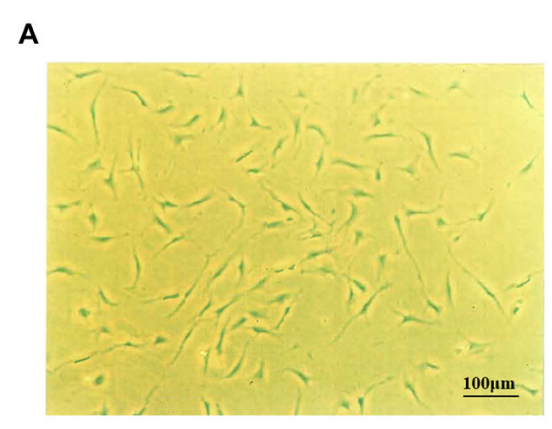

D

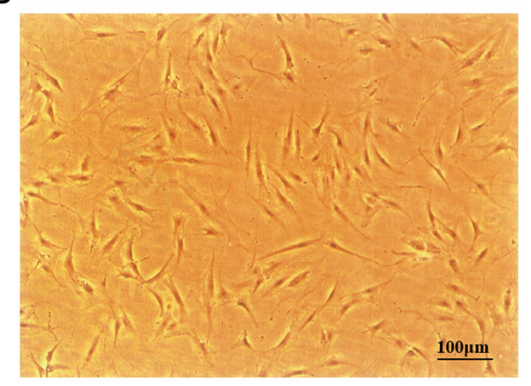

B

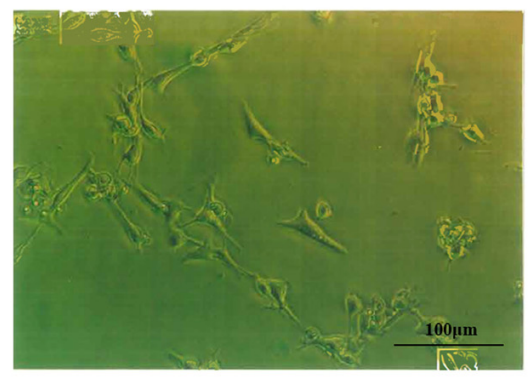

E

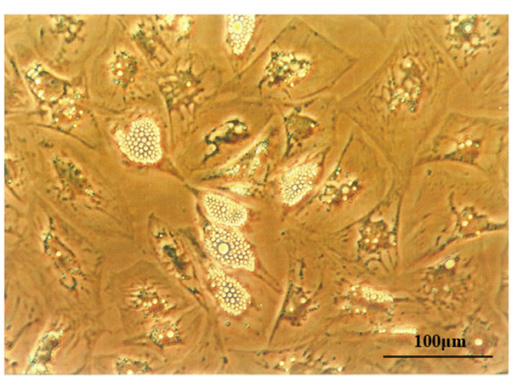

C

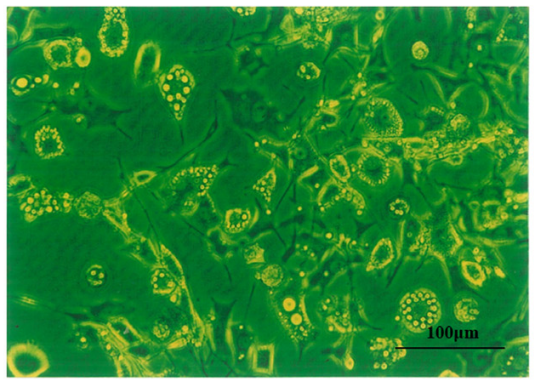

$\mathbf{F}$

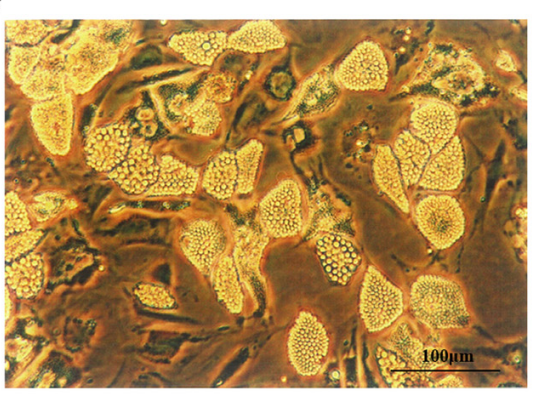

FIGURE 1 | 3T3-L1 and human primary preadipocytes proliferation and differentiation. (A) 3T3-L1 preadipocyte on Day 4 (×100). Adipocytes on Day 4 (B) and Day 14 (C) after inducing differentiation (×200). (D) Human primary preadipocyte on Day 8 (×100). Adipocytes on Day 10 (E) and Day 18 (F) after inducing differentiation ( $\times 200)$. Magnification: $\times 100$ or $\times 200$.

enhanced the proliferation of human primary preadipocytes $(107.8 \pm 2.8$ vs. $100.0 \pm 3.6, p<0.05)$. This stimulatory effect was not observed at lower concentrations $(0.1$ and $10 \mathrm{ng} / \mathrm{ml})$. Figure 2D showed the time curve of ghrelin on human primary preadipocytes proliferation, and the OD value of human cell controls also gradually upregulated which was consistent with the observations of mouse 3T3-L1 cells. After adding $1000 \mathrm{ng} / \mathrm{ml}$ ghrelin to these cells, the OD value of the cells further increased from 4 to $72 \mathrm{~h}$, and they became significantly higher than that of the control group from $24 \mathrm{~h}(154.8 \pm 5.4$ vs. $140.9 \pm 5.1, p<0.05)$ to $48 \mathrm{~h}(204.1 \pm 6.1$ vs. $192.1 \pm 4.2, p<0.05)$, but this stimulatory effect disappeared at $72 \mathrm{~h}$.

CCK-8 was used to further evaluate the effect of ghrelin on the proliferation of 3T3-L1 preadipocytes. As shown in Figures 2E,F, 1, 10, and $100 \mathrm{ng} / \mathrm{ml}$ ghrelin stimulated cell proliferation at $24 \mathrm{~h}$ (Figure 2E, $p<0.05$ ), but the concentrations showed no significant difference at $48 \mathrm{~h}$ compared with the control group (Figure 2F). These results were consistent with the MTT assay as shown in Figures 2A,B.

3T3-L1 preadipocytes were treated with $0.25-100 \mathrm{ng} / \mathrm{ml}$ ghrelin for $24 \mathrm{~h}$ (Figure 2G). Similar to the administration of ghrelin, $0.25 \mathrm{ng} / \mathrm{ml}$ IGF-1 could significantly enhance cell growth compared with the control group (105.9 \pm 5.2 vs. $100.0 \pm 4.9$, $p<0.05)$, and this effect was concentration-dependent. The maximum promotion effect was observed at $100 \mathrm{ng} / \mathrm{ml}$, which was up to $134 \%$ compared with the control group $(p<0.05)$. IGF1 also presented a similar concentration-dependent stimulatory effect in human cells (Figure $\mathbf{2 H}$ ), with the maximum effect of $131.2 \%$ at $100 \mathrm{ng} / \mathrm{ml}$.

\section{Ghrelin Upregulated the Expression of IGF-1 in 3T3-L1 and Human Preadipocytes}

IGF-1 is a growth factor known to promote cell proliferation. To determine whether IGF-1 is involved in the proliferation of 3T3L1 preadipocytes, the cells were treated with $10 \mathrm{ng} / \mathrm{ml}$ ghrelin for 4,8 , and $24 \mathrm{~h}$, and the levels of IGF-1 mRNA were assessed using RT-PCR. As presented in Figure 3A, ghrelin significantly increased the expression of IGF- 1 mRNA at 4,8 , and $24 \mathrm{~h}$, which was 6.15 times that of the of controls at $4 \mathrm{~h}(p<0.05)$, and 1.32fold of that at both $8 \mathrm{~h}(p<0.05)$ and $24 \mathrm{~h}(p<0.05)$, suggesting that IGF-1 may be involved in the stimulatory proliferation of ghrelin in 3T3-L1 cells. To further confirm the hypothesis, the various dilutions of IGF-1 antibodies (1:500, 1:1000, 1:5000) were added together with $10 \mathrm{ng} / \mathrm{ml}$ ghrelin. As presented in Figure 3B, the stimulatory effect of ghrelin was attenuated only with the 1:500 IGF-1 antibody dilution by $17.8 \%$ (95.7 \pm 6.0 vs. $116.4 \pm 6.5 ; p<0.05)$, whereas no significant changes were observed at the lower dilutions of 1:1000 $(p>0.05)$ and 1:5000.

Consistent with the observation in 3T3-L1 preadipocytes, the OD value of human primary preadipocytes also decreased after mixing with $1000 \mathrm{ng} / \mathrm{ml}$ ghrelin and 1:5000 IGF-1 antibody, indicating that the promotional effect of ghrelin on human preadipocytes was also through IGF-1. However, compared with the mouse cells, a low concentration (1:5000) of IGF-1 antibody was capable to attenuate the stimulatory action of $1000 \mathrm{ng} / \mathrm{ml}$ ghrelin (102.6 \pm 3.5 vs. $107.8 \pm 2.8 ; p=0.0175)$ in human cells (Figure 3C). These results suggest that ghrelin affects the 
A

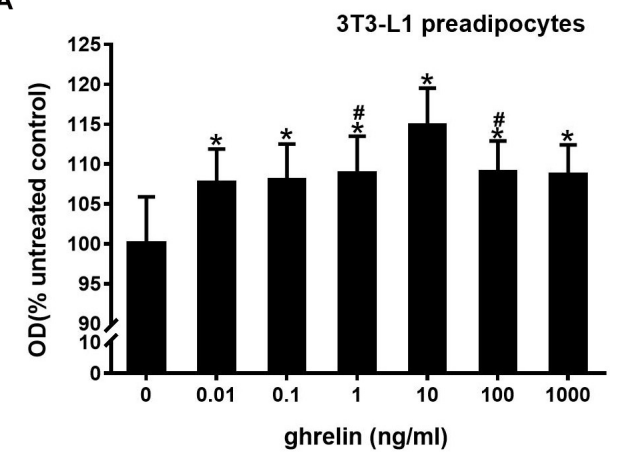

C

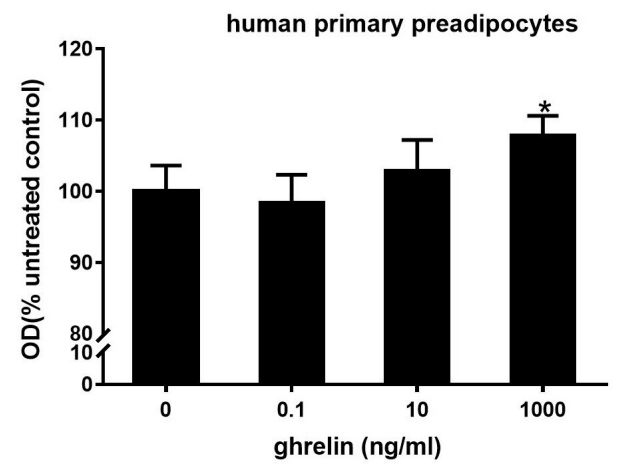

E

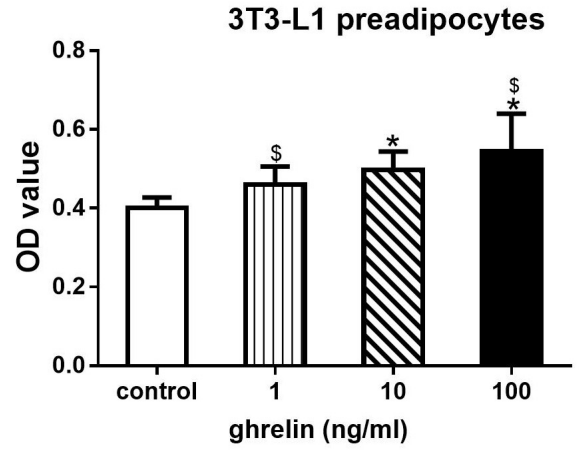

G

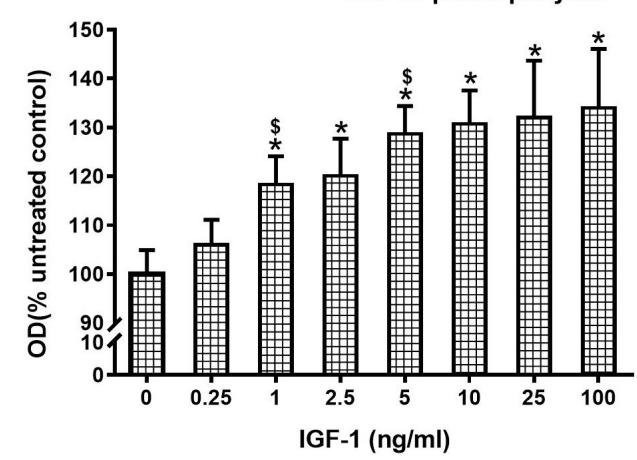

B

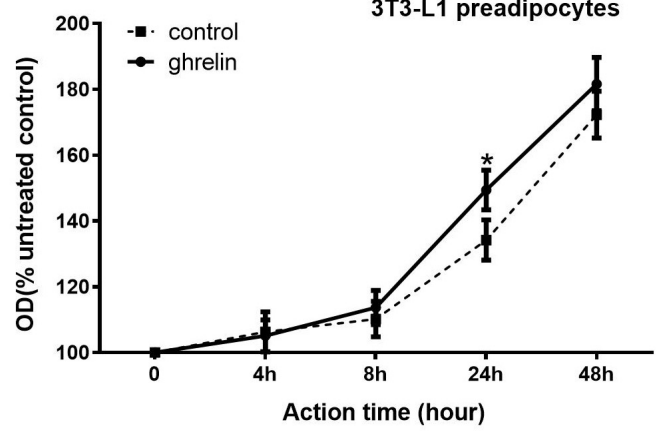

D

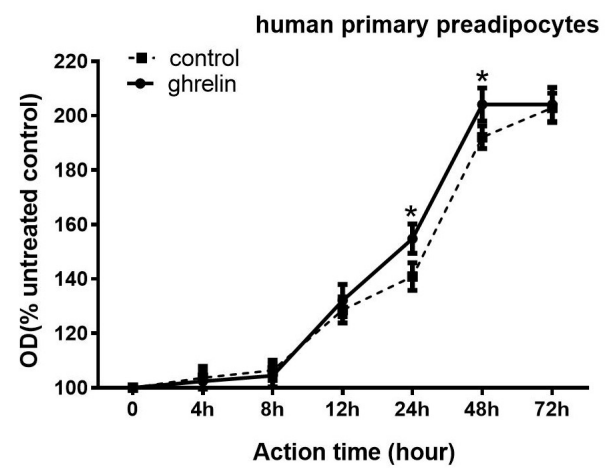

$\mathbf{F}$

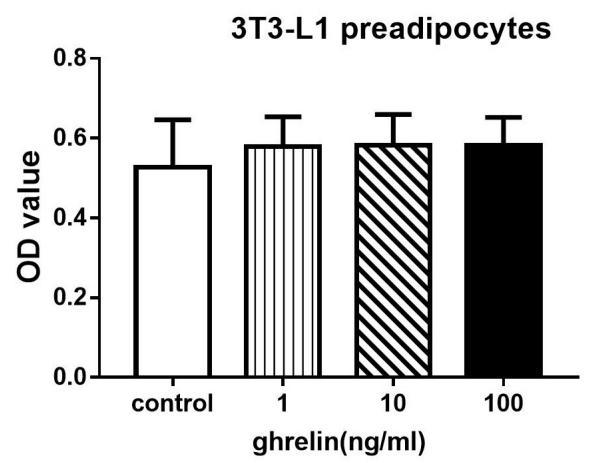

H

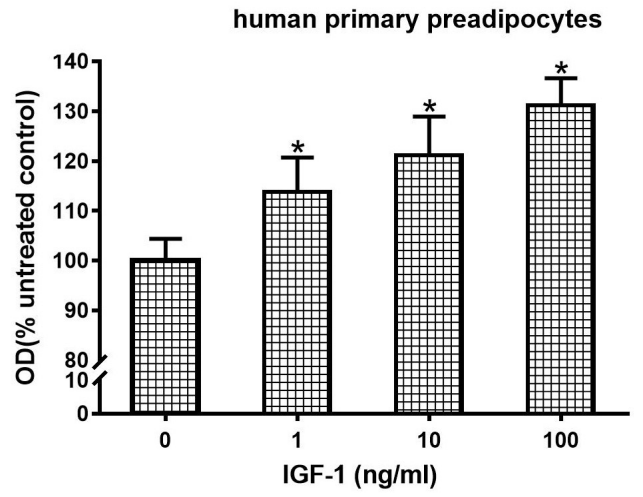

FIGURE 2 | Ghrelin and IGF-1 stimulated the proliferation of mouse 3T3-L1 preadipocytes and human primary preadipocytes. Effect of ghrelin on 3T3-L1 preadipocytes at indicated concentrations (A) and time (B). Effect of ghrelin on human primary preadipocytes at indicated concentrations (C) and time (D). CCK-8 measurement of 3T3-L1 preadipocytes for $24 \mathrm{~h}(\mathbf{E})$ or $48 \mathrm{~h} \mathbf{( F )}$. Effect of ghrelin on 3T3-L1 preadipocytes at indicated concentrations (G) and time (H). The data are presented as the mean \pm SD for six $\mathbf{( A , C , G , H )}$ or three $\mathbf{( B , D , E , F ) ~ i n d e p e n d e n t ~ e x p e r i m e n t s ~ w i t h ~ e i g h t ~ i n d i v i d u a l ~ w e l l s ~ i n ~ e a c h ~ e x p e r i m e n t . ~}{ }^{*} p<0.05$ vs. control group, \#p < 0.05 vs. $10 \mathrm{ng} / \mathrm{ml}$ ghrelin group, $\$ p<0.05$ in two groups. 
A
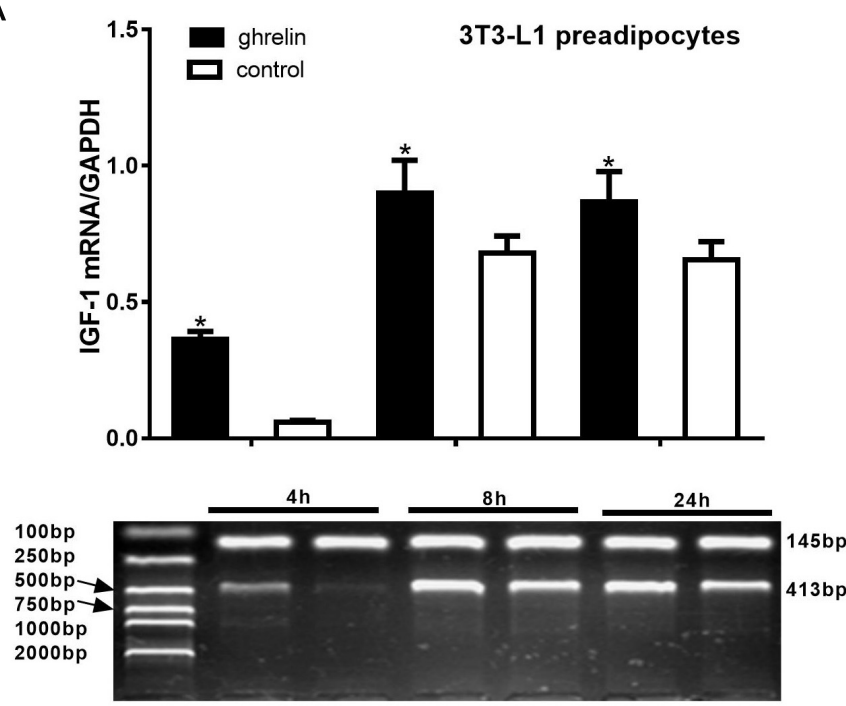

B

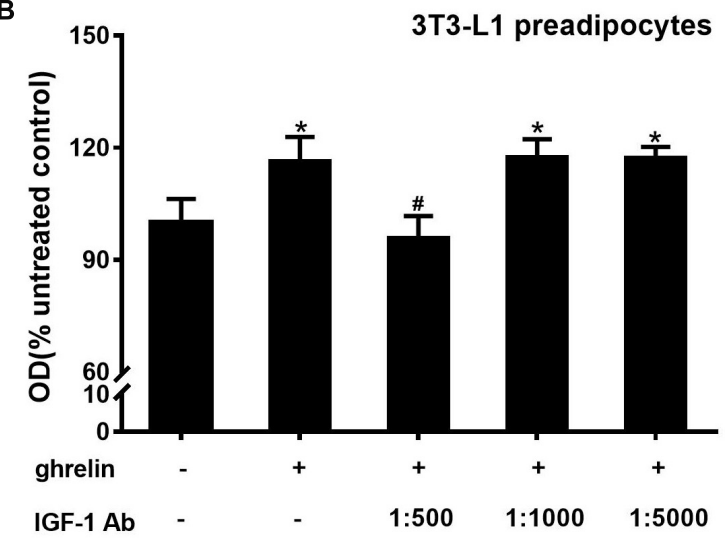

C

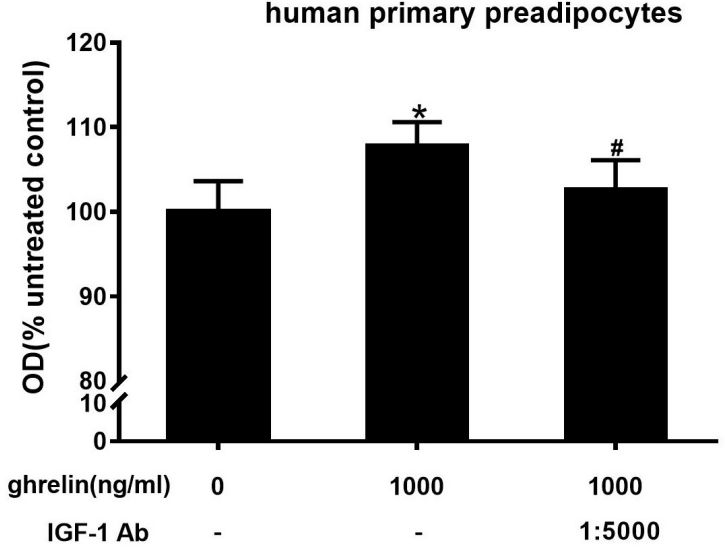

FIGURE 3 | Ghrelin upregulated the expression of IGF-1 in 3T3-L1 and human preadipocytes. Effects of ghrelin on IGF-1 mRNA levels in 3T3-L1 preadipocytes (A). Effect of IGF-1 antibody on the proliferation of 3T3-L1 preadipocytes (B) and human primary preadipocytes (C). The data are presented as the mean \pm SD for three independent experiments with eight individual wells in each experiment. ${ }^{*} p<0.05 \mathrm{vs.} 0 \mathrm{ng} / \mathrm{ml}$ ghrelin group, $\# p<0.05$ vs. ghrelin group.

proliferation of mouse and human preadipocytes directly by upregulating IGF-1 expression.

3T3-L1 preadipocytes were treated with 1,10 , and $100 \mathrm{ng} / \mathrm{ml}$ for $24 \mathrm{~h}$, then qRT-PCR was conducted to explore whether ghrelin can affect cell proliferation and apoptosis. As shown in Figure 4, cell proliferation-related genes including cyclin $\mathrm{D} 1, \mathrm{E} 1, \mathrm{~B} 2$ and apoptosis-related genes including BAX, Bcl-2, $\mathrm{Bcl}-\mathrm{xL}$ were measured. Compared with the control groups, the expression of cyclins and apoptosis genes showed no significant difference after administrating ghrelin. The results suggest that ghrelin-induced 3T3-L1 cell proliferation may not be mediated through the genes we investigated in the present study.

\section{Ghrelin Suppressed While IGF-1 Stimulated the Differentiation of 3T3-L1 and Human Adipocytes}

Oil Red $O$ staining can indirectly assess triglycerides in the cytoplasm of differentiated adipocytes. To investigate the effect of ghrelin on the differentiation of 3T3-L1 preadipocytes, these cells were treated with $0.1,10$, and $1000 \mathrm{ng} / \mathrm{ml}$ ghrelin for 1,3 , and 6 days. In this study as depicted in Figure 5A, we found that $0.1 \mathrm{ng} / \mathrm{ml}$ ghrelin significantly suppressed the $\mathrm{OD}$ values on the $1^{\text {st }}$ day after differentiation by $27.7 \%$ compared with the control group $(p<0.05)$. The inhibitory effect was observed at 10 and $1000 \mathrm{ng} / \mathrm{ml}$ ghrelin on days 1,3 and 6 as well, but this effect was not further enhanced with the increase of doses and the extension of action time.

As the enzyme G-3-PDH is specifically expressed in differentiating adipocytes, we further investigated the effect of ghrelin on G-3-PDH activity. $10 \mathrm{ng} / \mathrm{ml}$ ghrelin was added to 3T3L1 preadipocytes in a serum-free differential medium for 1,3 and 6 days, and G-3-PDH activity was measured. As shown in Figure 5B, ghrelin could suppress G-3-PDH enzyme activities as expected, but it was only significantly decreased by $13.2 \%$ on the $3^{\text {rd }}$ day after differentiation $(p<0.05)$.

The experiments discussed above suggested that ghrelin inhibited the differentiation of 3T3-L1 preadipocytes based on triglyceride content and G-3-PDH activity. Consistent with the results of the mouse 3T3-L1 cells, the OD values of the human differentiating adipocytes also decreased with administration of 0.1 to $1000 \mathrm{ng} / \mathrm{ml}$ ghrelin for 4,8 , and 12 days (Figure $5 \mathrm{C}$ ), but the 


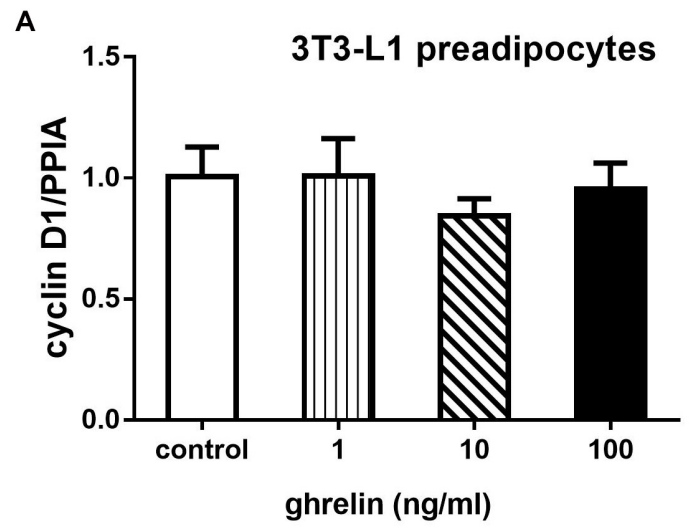

C

3T3-L1 preadipocytes

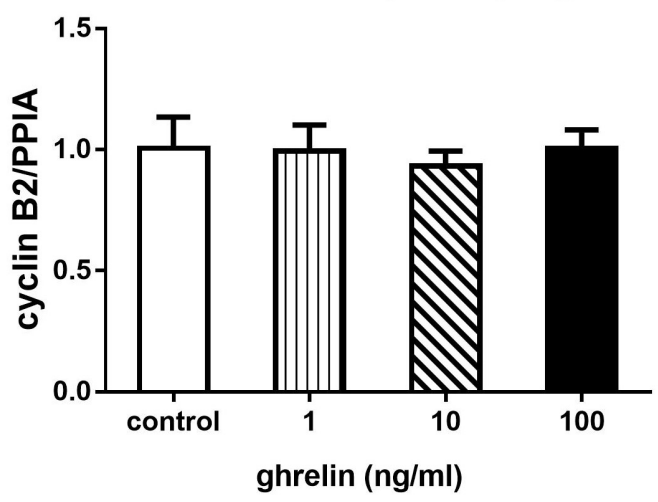

$\mathbf{E}$

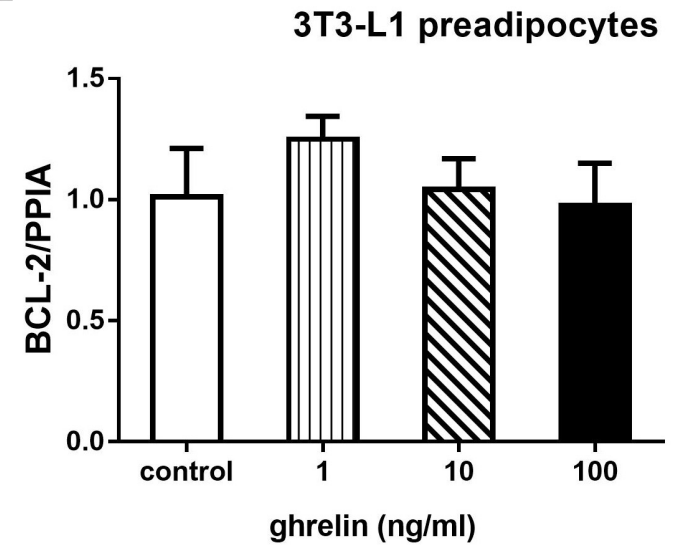

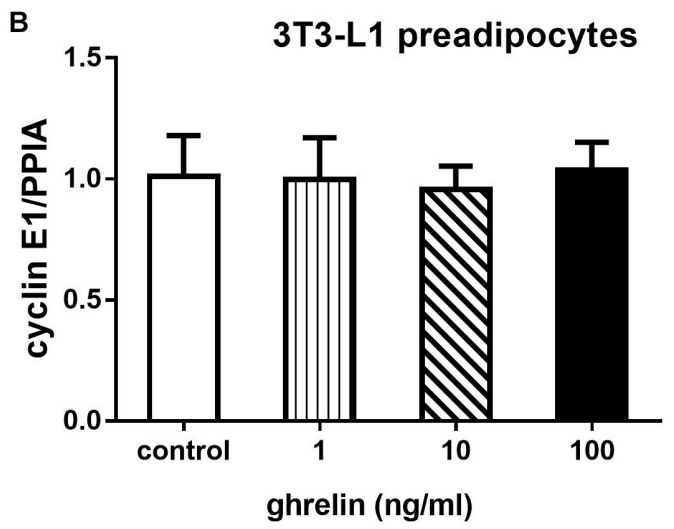

D

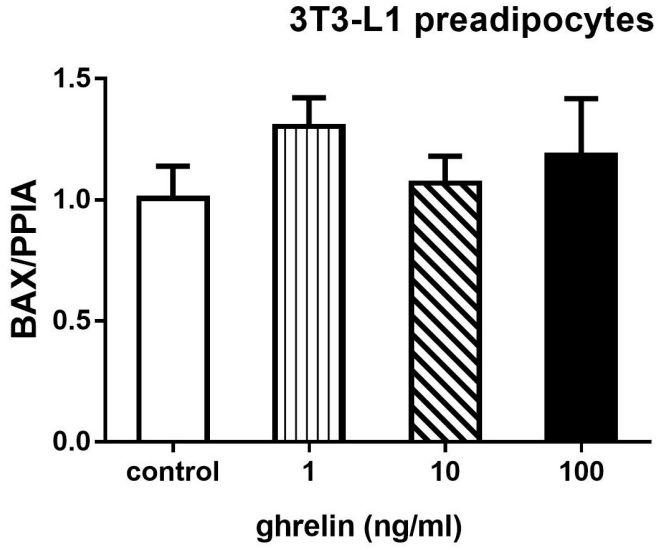

$\mathbf{F}$

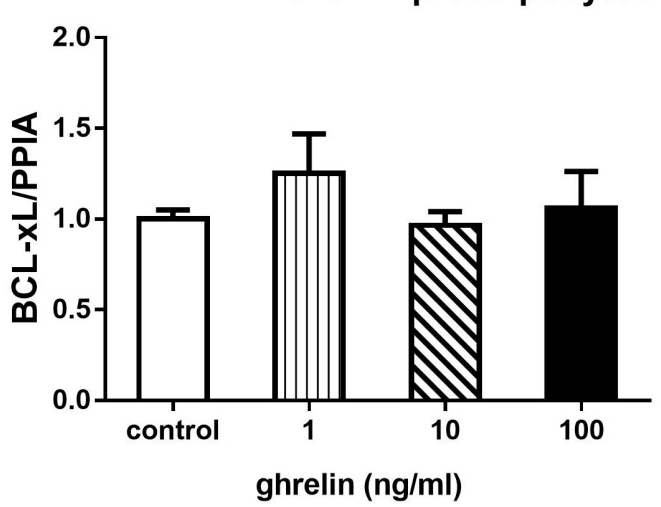

FIGURE 4 | Effects of ghrelin on proliferation and apoptosis-related genes expression in 3T3-L1 preadipocytes. The mRNA levels of cyclin D1, E1, B2, and apoptosis genes BAX, Bcl-2, Bcl-xL were determined by RT-qPCR analysis (A-F). The data are presented as the mean \pm SD for three independent experiments with three wells in each experiment. ${ }^{*} p<0.05 \mathrm{vs.} 0 \mathrm{ng} / \mathrm{ml}$ ghrelin group.

significant results were observed only on days 8 and 12 following the differentiation $(p<0.05)$.

Figure 5D showed the activity of G-3-PDH in human differentiating adipocytes. After treating with $10 \mathrm{ng} / \mathrm{ml}$ ghrelin in a differential medium, the G-3-PDH activity of the cells reduced by $12.4 \%(150.4 \pm 7.2$ vs. $131.7 \pm 8.1, p<0.05), 10.5 \%$
$(313.2 \pm 10.7$ vs. $280.4 \pm 10.1, p<0.05)$ and $9.3 \%(552.9 \pm 10.4$ vs. $501.4 \pm 16.4, p<0.05$ ) on days 4,8 , and 12 , respectively.

3T3-L1 preadipocytes were treated with $1,10,100 \mathrm{ng} / \mathrm{ml} \mathrm{IGF-}$ 1 for 1,3 , and 6 days. In contrast to the observation of ghrelin, as shown in Figure 5, IGF-1 enhanced the OD values (Figure 5E) and G-3-PDH activity (Figure 5F) of 3T3-L1 cells on days 1, 
A

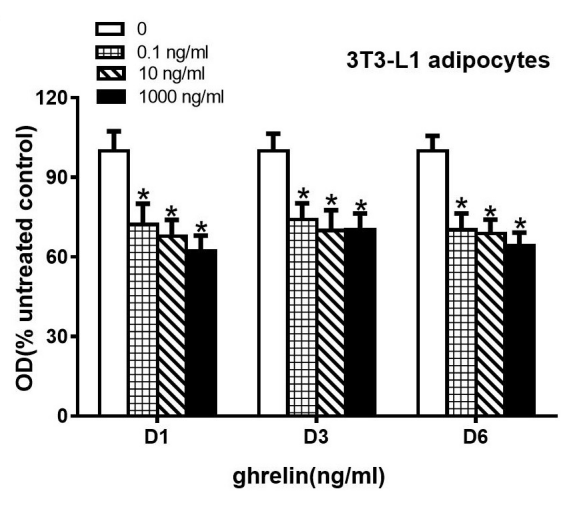

C

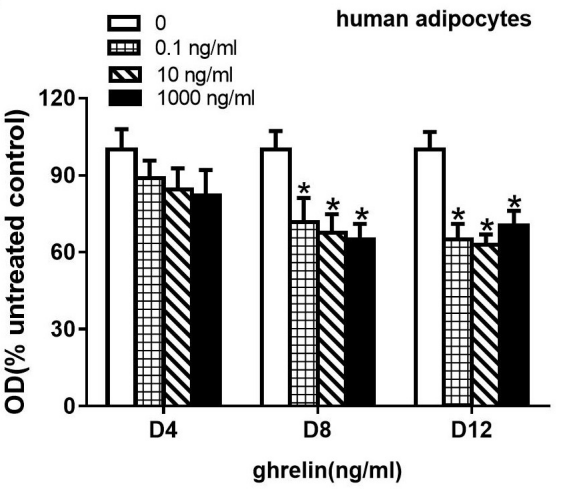

E

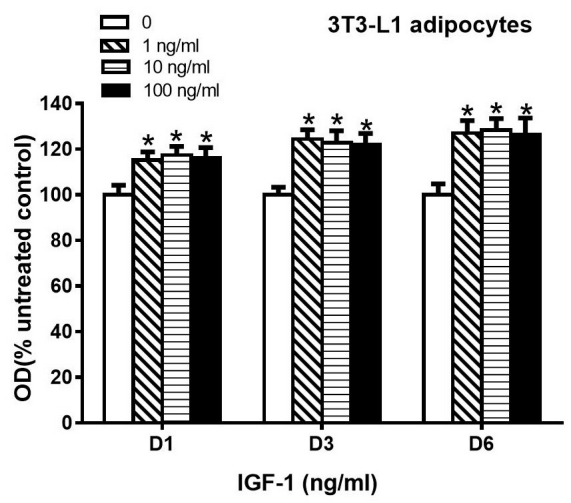

G

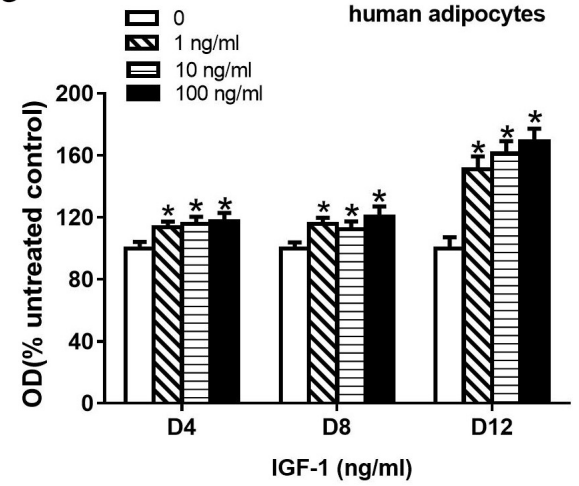

B

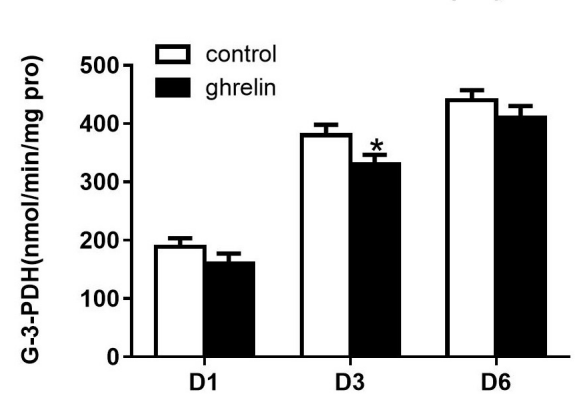

D

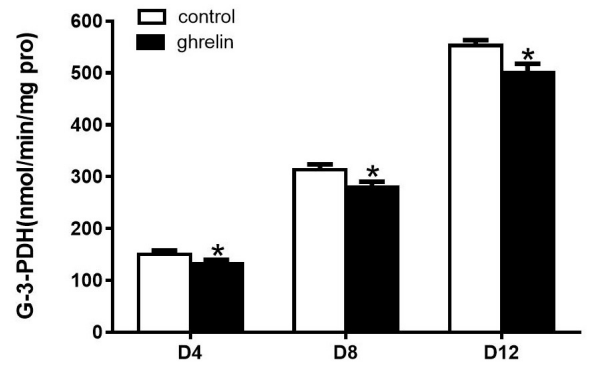

F 3T3-L1 adipocytes

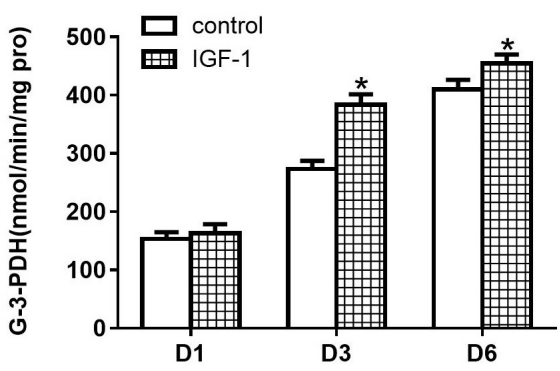

H

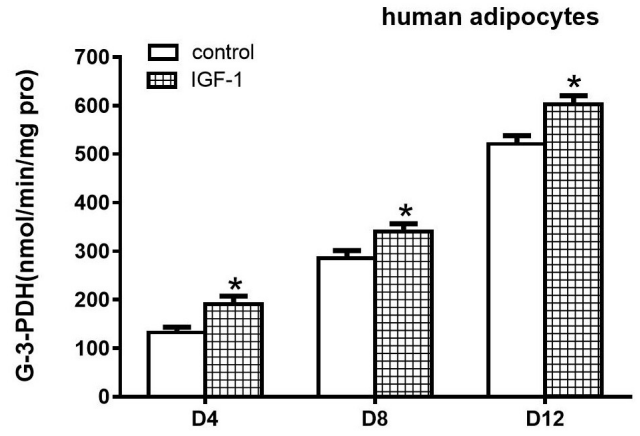

FIGURE 5 | Ghrelin suppressed while IGF-1 stimulated the differentiation of 3T3-L1 and human primary preadipocytes. Differentiation was measured based on Oil

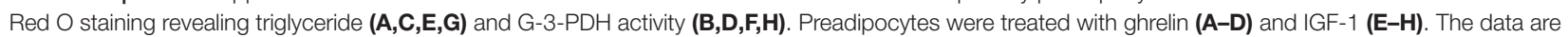
presented as the mean \pm SD for three independent experiments with eight $(\mathbf{A}, \mathbf{C}, \mathbf{E}, \mathbf{G})$ or three $\mathbf{( B , D , F , H ) ~ i n d i v i d u a l ~ w e l l s ~ i n ~ e a c h ~ e x p e r i m e n t . ~}{ }^{*} p<0.05$ vs. control group. 
A
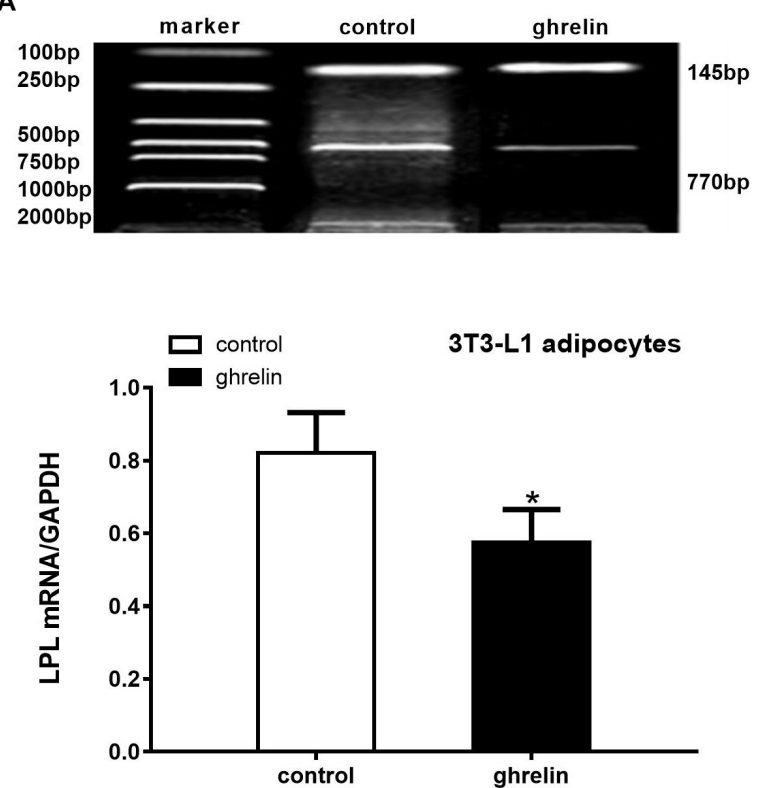

B
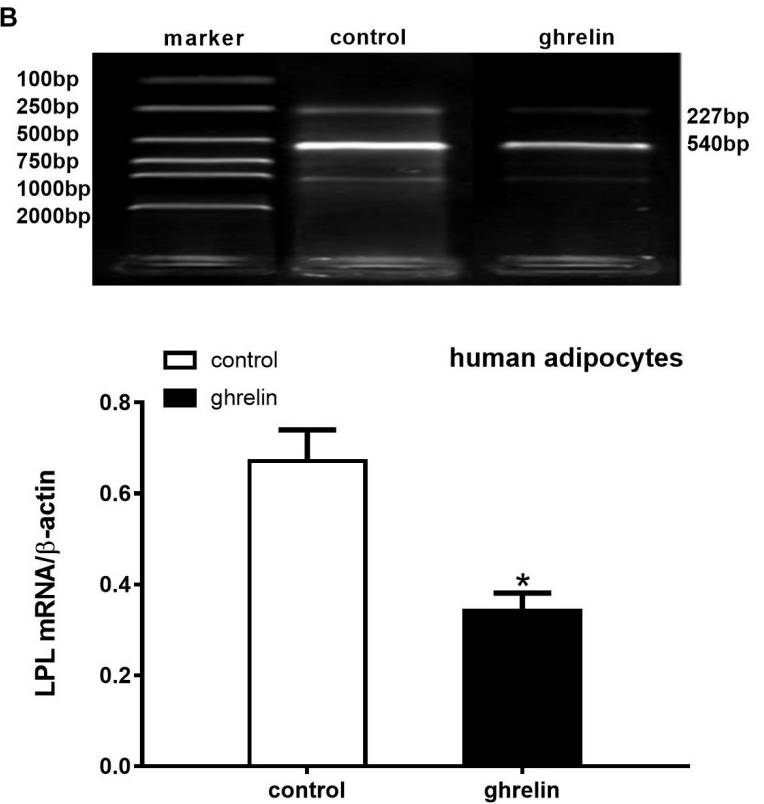

FIGURE 6 | Ghrelin inhibited the LPL mRNA levels in 3T3-L1 and human differentiating adipocytes. Levels of LPL mRNA in 3T3-L1 (A) and human adipocytes (B) were measured by RT-PCR after treatment with $10 \mathrm{ng} / \mathrm{ml}$ ghrelin. LPL (770 bp) and GAPDH (145 bp) in 3T3-L1 preadipocytes, as well as LPL (227 bp) and $\beta$-actin (540 bp) in human adipocytes are shown with molecular markers in the upper panel of $\mathbf{( A , B ) . ~ I n ~ t h e ~ l o w e r ~ p a n e l , ~ d a t a ~ w e r e ~ c a l c u l a t e d ~ u s i n g ~ t h e ~ d e n s i t y ~ r a t i o ~ o f ~ L P L ~}$ to GAPDH (A) and $\beta$-actin PCR products (B). The data are presented as the mean \pm SD for three independent experiments. $* p<0.05$ vs. control group.

3, and 6. The stimulatory effect was also observed in human adipocytes, as depicted in Figures 5G,H. These results indicated that IGF-1 promoted the differentiation of both murine and human adipocytes.

\section{Ghrelin Inhibited the LPL mRNA Levels in 3T3-L1 and Human Differentiating Adipocytes}

Because LPL is an essential enzyme expressed in the early stages of adipocyte differentiation, it has been widely used to investigate the effect of hormones on the differentiation of preadipocytes. To determine whether ghrelin can modulate the expression of this enzyme in mouse and human adipocytes, LPL mRNA levels were measured after adding ghrelin for 8 days following differentiation. As presented in Figure 6, we found that LPL mRNA decreased by $30.2 \%$ (0.574 \pm 0.092 vs. $0.822 \pm 0.110$, $p<0.05$ ) in 3T3-L1 adipocytes (Figure 6A) and by $49.0 \%$ $(0.342 \pm 0.039$ vs. $0.671 \pm 0.069, p<0.05)$ in human adipocytes (Figure 6B) compared with the control groups, which indicated that ghrelin significantly inhibited the lipid metabolism of mouse and human differentiating adipocytes.

\section{Ghrelin Suppressed the Expression of PPAR $\gamma 2$ and $C / E B P \alpha$ mRNA in Human Differentiating Adipocytes}

$\mathrm{PPAR} \gamma 2$ and $\mathrm{C} / \mathrm{EBP} \alpha$ are two important transcription factors that can activate and mediate synergistically in the differentiation of preadipocytes. To clarify the effect of ghrelin on these adipogenic markers, the expression of PPAR $\gamma 2$ (Figure 7A) and
$\mathrm{C} / \mathrm{EBP} \alpha$ (Figure 7B) were analyzed on day 8 after inducing differentiation. In accordance with the expectations, the levels of PPAR $\gamma 2$ and $\mathrm{C} / \mathrm{EBP} \alpha \mathrm{mRNA}$ were markedly suppressed by $28.2 \%$ ( $0.642 \pm 0.077$ vs. $0.894 \pm 0.091, p<0.05)$ and $30.1 \%(0.302 \pm 0.069$ vs. $0.432 \pm 0.039, p<0.05)$ compared with the controls, suggesting that $\operatorname{PPAR} \gamma 2$ and $\mathrm{C} / \mathrm{EBP} \alpha$ were involved in the inhibitory differentiation of ghrelin in human differentiating adipocytes.

\section{Ghrelin Downregulated the Expression of PPAR 2 and ACC mRNA in 3T3-L1 Adipocytes}

Acetyl-CoA carboxylase is an essential enzyme for fatty acid synthesis. 3T3-L1 preadipocytes were treated with 1, 10, and $100 \mathrm{ng} / \mathrm{ml}$ ghrelin for 8 days after inducing to differentiation. As depicted in Figure 8, $100 \mathrm{ng} / \mathrm{ml}$ ghrelin suppressed mRNA levels of PPAR $\gamma 2$ (Figure 8A) and ACC (Figure 8D) compared with the control groups $(p<0.05)$.

\section{DISCUSSION}

Ghrelin is a 28 -amino-acid peptide that has been widely found to regulate energy homeostasis, glucose and lipid metabolism, and its receptor, GHS-R1a has been expressed in rodent and human adipocytes (Kim et al., 2004; Rodriguez et al., 2009; Miegueu et al., 2011). Our study demonstrated that ghrelin promoted the proliferation of mouse 3T3-L1 and human primary preadipocytes by increasing IGF-1 expression, and IGF-1 also enhanced the proliferation of murine and human cells. 
A
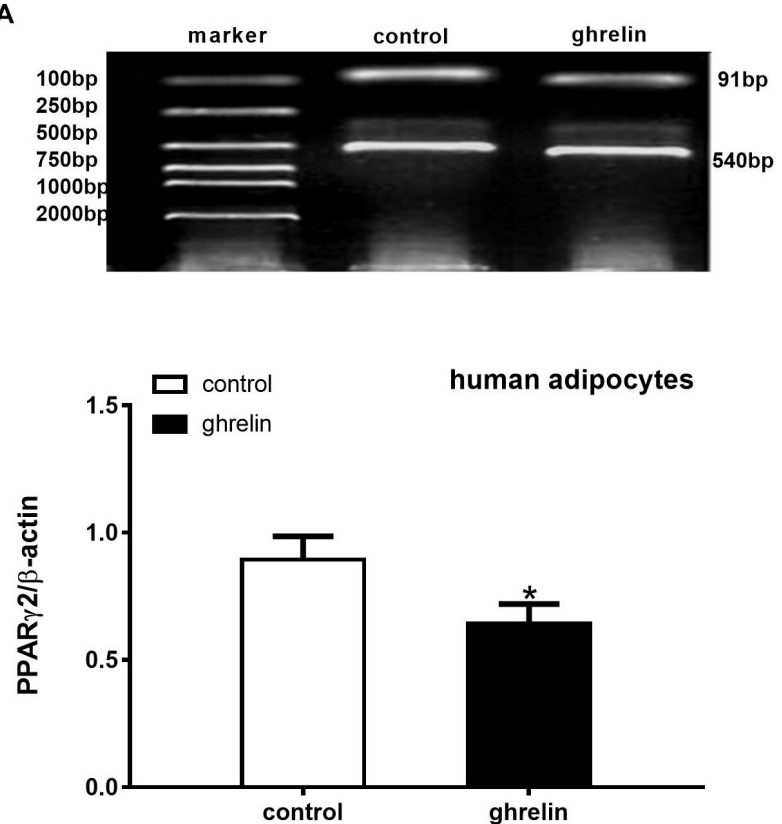

B
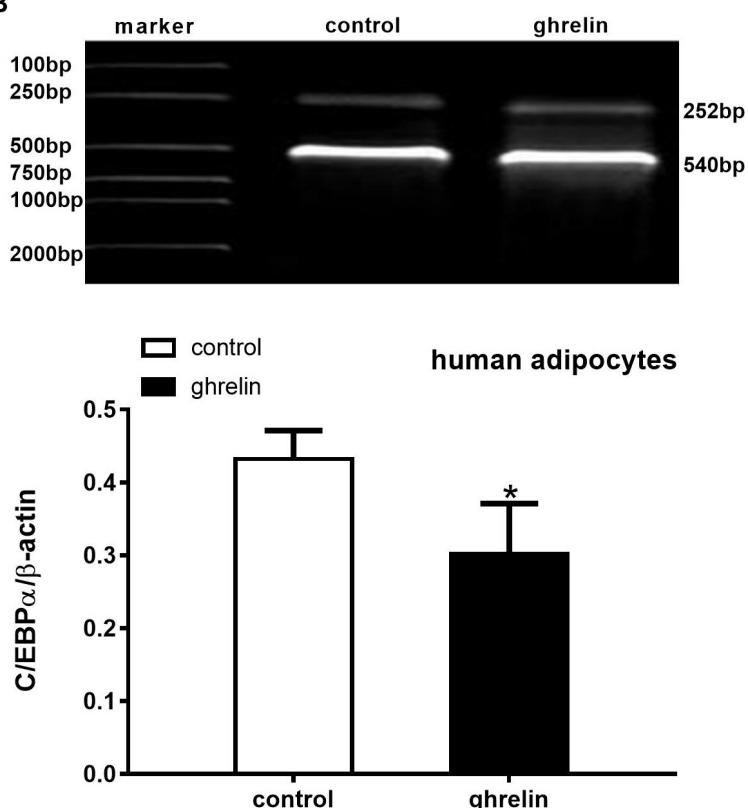

FIGURE 7 | Ghrelin suppressed the expression of PPAR $\gamma 2$ and C/EBP $\alpha$ mRNA in human differentiating adipocytes. Levels of PPAR 2 (A) and C/EBP $\alpha$ (B) mRNA in human differentiating adipocytes were measured using RT-PCR after treatment with $10 \mathrm{ng} / \mathrm{ml}$ ghrelin. The data are presented as the mean \pm SD for three independent experiments. ${ }^{*} p<0.05$ vs. control group.

In contrast, IGF-1 promoted differentiation, whereas ghrelin inhibited the differentiation and lipid accumulation of adipocytes by downregulating the expression of the transcription factors PPAR $\gamma 2$ and $C / E B P \alpha$.

Substantial evidence has shown that ghrelin is capable of stimulating 3T3-L1 cell growth (Kim et al., 2004; Liu et al., 2009; Miegueu et al., 2011), and it significantly increased cell numbers at concentrations from $10^{-7}$ to $10^{-15} \mathrm{~mol} / \mathrm{L}$ (equal to 330 to $3.3 \times 10^{-6} \mathrm{ng} / \mathrm{ml}$ ), which is consistent with our results. The study performed by Liu et al. (2009) showed that after $24 \mathrm{~h}$ of treatment, ghrelin $\left(10^{-7}, 10^{-11}\right.$ to $\left.10^{-15} \mathrm{~mol} / \mathrm{L}\right)$ promoted 3T3$\mathrm{L} 1$ preadipocyte proliferation, and $10^{-9}$ and $10^{-11} \mathrm{~mol} / \mathrm{L}$ ghrelin also presented a stimulatory effect at $6 \mathrm{~h}$. In our study, we found that the $10 \mathrm{ng} / \mathrm{ml}$ ghrelin stimulated 3T3-L1 cell growth at $24 \mathrm{~h}$. A similar effect on human primary preadipocyte proliferation was also observed, but it was at a higher concentration (1000 ng/ml) compared with 3T3-L1 cells. Because the expression of ghrelin receptor-GHSR has been found in both human and rodent adipocytes, an explanation may be the difference in the receptor number and affinity of these two species. Rat ghrelin was used in our present study, and it may have higher affinity with the receptors of murine 3T3-L1 preadipocytes than human preadipocytes (Kos et al., 2009; Rodriguez et al., 2009; Gurriaran-Rodriguez et al., 2011). In addition to the promotional effect on proliferation of mouse 3T3-L1 and human primary preadipocytes, ghrelin is capable of enhancing the growth of other types of cells, such as cardiomyocytes, osteoblasts, murine $\mathrm{T}$ cells, and gastric and colorectal cancer cells. In these cells, ghrelin promotes proliferation in a dose-dependent or timedependent manner (Pettersson et al., 2002). The doses and action times are distinguished by the type of cells; for example, ghrelin significantly enhanced cell growth at concentrations from 1 to $100 \mathrm{nmol} / \mathrm{L}$ (equal to 3.3 to $330 \mathrm{ng} / \mathrm{ml}$ ) in gastric cancer cells (Tian et al., 2013), but 3 to $30 \mu \mathrm{mol} / \mathrm{L}$ (equal to 9.9 to $99 \times 10^{3}$ $\mathrm{ng} / \mathrm{ml}$ ) in cardiomyocytes (Pettersson et al., 2002). Considering the action time of ghrelin, murine $\mathrm{T}$ cells with ghrelin generally exhibited greater proliferation than the controls at 12 to $48 \mathrm{~h}$ (Lee et al., 2014). These studies suggest a wide growth-promotional effect of ghrelin on cells and tissues.

Previous studies have shown that ghrelin upregulated c-Myc protein, a cell cycle activator inducing transition from the G1 phase to $S$ phase, and this mitogenic effect might be due to the activation of the phosphatidylinositol 3-kinase (PI3K)/Akt and ERK1/2 pathways (Kim et al., 2004; Liu et al., 2009; Miegueu et al., 2011). In our study, we found that ghrelin promoted mouse 3T3-L1 and human primary preadipocyte proliferation by directly upregulating the expression of IGF-1, and it was further confirmed by using IGF-1 antibody, which abolished the stimulatory proliferation action of ghrelin in both murine and human preadipocytes. The results of the qRT-PCR showed that the mRNA levels of cyclin genes cyclin D1, E1, B2 and apoptosis genes $\mathrm{BAX}, \mathrm{Bcl}-2, \mathrm{Bcl}-\mathrm{xL}$ had no significant difference in ghrelin and control groups. These findings suggested that the stimulatory effect of ghrelin may be not by increasing cyclins and decreasing apoptosis. The addition of IGF-1 to preadipocytes could also promote cell growth. Studies performed by Kim et al. (2004) also support our results, showing that IGF-1 could increase the number of 3T3-L1 preadipocytes. Ku et al. (2012) found that IGF-1 suppressed apoptosis induced by serum starvation. 
A

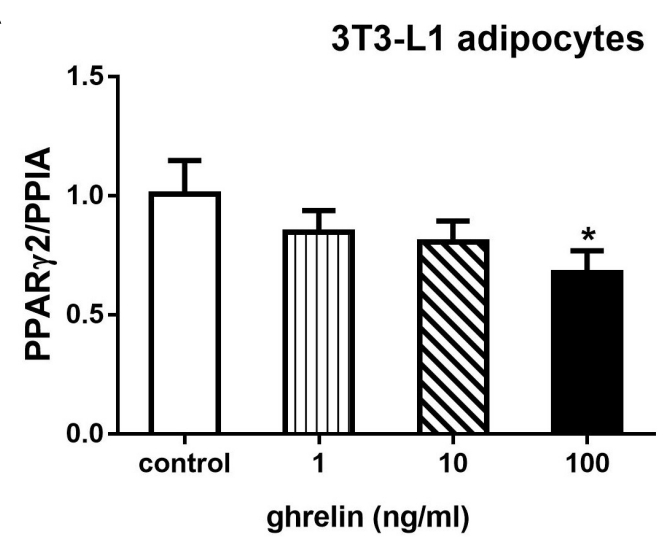

C

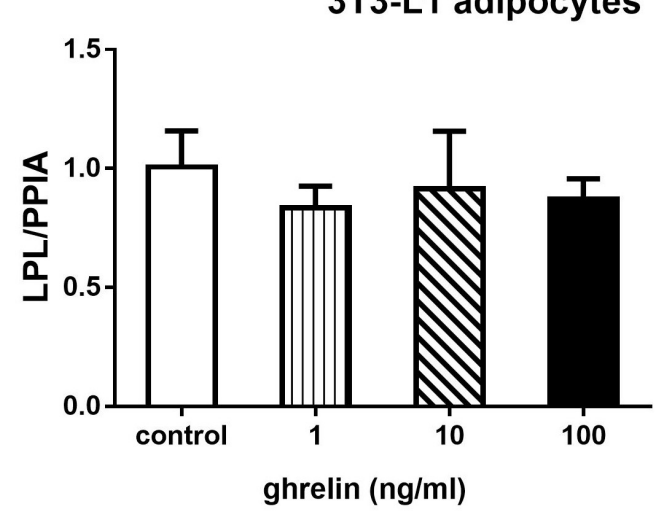

B

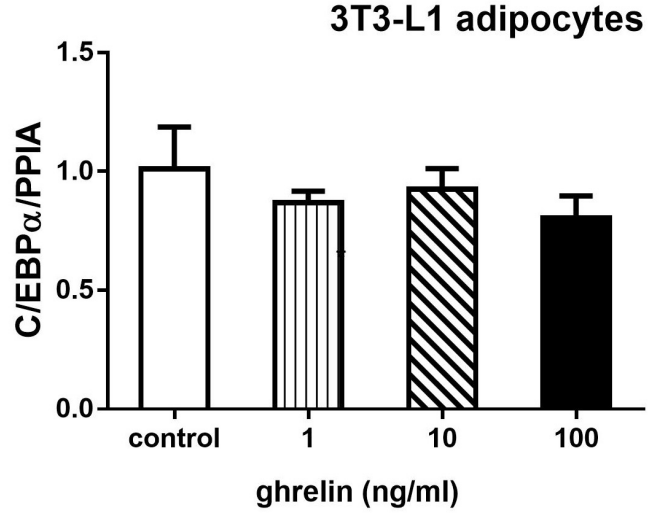

D

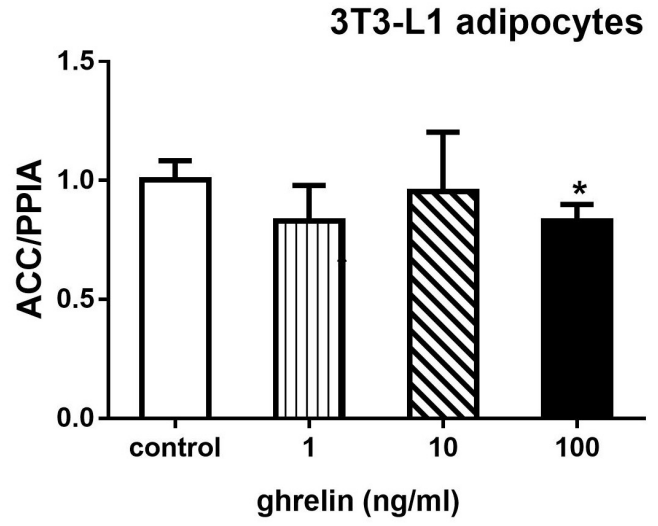

FIGURE 8 | Ghrelin downregulated the expression of PPAR 2 and ACC mRNA in 3T3-L1 differentiating adipocytes. The mRNA levels of PPAR 2 (A), C/EBP $\alpha$ (B), LPL (C), and ACC (D) were determined by determined by RT-qPCR analysis. The data are presented as the mean \pm SD for three independent experiments with three wells in each experiment. ${ }^{*} p<0.05$ vs. $0 \mathrm{ng} / \mathrm{ml}$ ghrelin group.

Several studies have reported that ghrelin stimulates the differentiation of mouse 3T3-L1 preadipocytes and enhances lipid accumulation by increasing the expression of PPAR $\gamma 2$ and C/EBPa (Kim et al., 2004; Liu et al., 2009; Miegueu et al., 2011). In these studies, the cells were supplemented with ghrelin at concentrations of $10^{-11}$ to $10^{-13} \mathrm{~mol} / \mathrm{L}$ (equal to 0.033 to $3.3 \times 10^{-4} \mathrm{ng} / \mathrm{ml}$ ) for 6 or 9 days. The stimulatory effect of ghrelin was also observed in human visceral adipocytes at concentrations of 10 to $1000 \mathrm{pmol} / \mathrm{L}$ (equal to 0.033 to $3.3 \mathrm{ng} / \mathrm{ml}$ ) (Rodriguez et al., 2009). In contrast, we found that ghrelin inhibited the differentiation of 3T3-L1 and human primary preadipocytes at $0.1,10$, and $1000 \mathrm{ng} / \mathrm{ml}$, and it suppressed the expression of lipogenesis enzymes. RT-PCR further suggested that the mechanism may be the downregulation of the adipogenic factors PPAR $\gamma 2$ and $\mathrm{C} / \mathrm{EBP} \alpha$. A study performed by Zhang et al. (2004) supported our finding, reporting that $10^{-6} \mathrm{~mol} / \mathrm{L}$ (equal to $3300 \mathrm{ng} / \mathrm{ml}$ ) inhibited preadipocytes differentiation. The stimulatory effect of ghrelin was observed at concentrations of $10^{-11}$ to $10^{-13} \mathrm{~mol} / \mathrm{L}$ in other studies, whereas 0.1 to $1000 \mathrm{ng} / \mathrm{ml}$ ghrelin inhibited differentiation in our study. A possible explanation may be that ghrelin is able to promote differentiation at low doses but markedly suppresses adipogenesis at the high doses. Interestingly, we found that ghrelin modulated proliferation by increasing IGF-1 levels (Figure 3), whereas IGF-1 promoted differentiation (Figures $\mathbf{5 G}, \mathbf{H}$ ), and another study also found that IGF-1 induced adipogenesis (Smith et al., 1988). Ghrelin may downregulate IGF-1 expression to inhibit the differentiation of preadipocytes, indicating it may have different effect on IGF-1 in cell proliferation and differentiation.

In the present study, we demonstrated that ghrelin downregulated the expression of lipogenesis enzymes, thereby reducing the lipid content in adipocytes. Additionally, ghrelin has been reported to have other effects on adipocytes, such as inhibition of lipolysis and anti-inflammation. In this regard, ghrelin suppresses lipolysis by activating of PI3K $\gamma / \mathrm{Akt}$ and phosphodiesterase (PDE) (Baragli et al., 2011; Miegueu et al., 2011) in mouse adipocytes and decreases aquaporin-7, a glycerol channel for lipid efflux, in human adipocytes (Rodriguez et al., 2009). Additionally, ghrelin also plays roles in anti-inflammatory processes by repressing TNF- $\alpha$-induced apoptosis and autophagy in adipocytes (Rodriguez et al., 2012), so ghrelin may be beneficial for human obesity and obesity-associated type 2 diabetes. 


\section{CONCLUSION}

Ghrelin enhanced the proliferation of 3T3-L1 and human primary preadipocytes by increasing the expression of IGF-1. Additionally, ghrelin inhibited the differentiation of mouse and human preadipocytes by downregulating PPAR $\gamma 2$ and $\mathrm{C} / \mathrm{EBP} \alpha$ levels. As a result, lipid accumulation and lipogenic enzymes consistently decreased.

\section{DATA AVAILABILITY STATEMENT}

All datasets generated for this study are included in the manuscript/Supplementary Files.

\section{AUTHOR CONTRIBUTIONS}

HM did the cell experiments, analyzed data, and wrote the primary manuscript. HP supervised the experiments. LW and HY helped to analyze data. HZ designed the experiments and

\section{REFERENCES}

Ailhaud, G. (1996). Early adipocyte differentiation. Biochem. Soc. Trans. 24, 400402. doi: 10.1042/bst0240400

Ashpole, N. M., Sanders, J. E., Hodges, E. L., Yan, H., and Sonntag, W. E. (2015). Growth hormone, insulin-like growth factor-1 and the aging brain. Exp. Gerontol. 68, 76-81. doi: 10.1016/j.exger.2014.10.002

Baragli, A., Ghe, C., Arnoletti, E., Granata, R., Ghigo, E., and Muccioli, G. (2011). Acylated and unacylated ghrelin attenuate isoproterenol-induced lipolysis in isolated rat visceral adipocytes through activation of phosphoinositide 3-kinase gamma and phosphodiesterase 3B. Biochim. Biophys. Acta 1811, 386-396. doi: 10.1016/j.bbalip.2011.03.001

Berry, R., Jeffery, E., and Rodeheffer, M. S. (2014). Weighing in on adipocyte precursors. Cell Metab. 19, 8-20. doi: 10.1016/j.cmet.2013.10.003

Choi, K., Roh, S. G., Hong, Y. H., Shrestha, Y. B., Hishikawa, D., Chen, C., et al. (2003). The role of ghrelin and growth hormone secretagogues receptor on rat adipogenesis. Endocrinology 144, 754-759. doi: 10.1210/en.2002-220783

Churm, R., Davies, J. S., Stephens, J. W., and Prior, S. L. (2017). Ghrelin function in human obesity and type 2 diabetes: a concise review. Obes. Rev. 18, 140-148. doi: $10.1111 /$ obr.12474

Corica, F., Bianchi, G., Corsonello, A., Mazzella, N., Lattanzio, F., and Marchesini, G. (2015). Obesity in the context of aging: quality of life considerations. Pharmacoeconomics 33, 655-672. doi: 10.1007/s40273-014-0237-8

Gao, M., Yang, J., Wei, R., Liu, G., Zhang, L., Wang, H., et al. (2013). Ghrelin induces cardiac lineage differentiation of human embryonic stem cells through ERK1/2 pathway. Int. J. Cardiol. 167, 2724-2733. doi: 10.1016/j.ijcard.2012. 06.106

Geloen, A., Collet, A. J., Guay, G., and Bukowiecki, L. J. (1989). Insulin stimulates in vivo cell proliferation in white adipose tissue. Am. J. Physiol. 256(1 Pt 1), C190-C196. doi: 10.1152/ajpcell.1989.256.1.C190

Gurriaran-Rodriguez, U., Al-Massadi, O., Crujeiras, A. B., Mosteiro, C. S., AmilDiz, M., Beiroa, D., et al. (2011). Preproghrelin expression is a key target for insulin action on adipogenesis. J. Endocrinol. 210, R1-R7. doi: 10.1530/joe-110233

Imai, T., Takakuwa, R., Marchand, S., Dentz, E., Bornert, J. M., Messaddeq, N., et al. (2004). Peroxisome proliferator-activated receptor gamma is required in mature white and brown adipocytes for their survival in the mouse. Proc. Natl. Acad. Sci. U.S.A. 101, 4543-4547. doi: 10.1073/pnas.0400356101

Kasprzak, A., and Adamek, A. (2012). The insulin-like growth factor (IGF) signaling axis and hepatitis $\mathrm{C}$ virus-associated carcinogenesis (review). Int. J. Oncol. 41, 1919-1931. doi: 10.3892/ijo.2012.1666 did the cell experiments. FG supervised the whole experiments and revised the primary manuscript. All authors contributed to manuscript revision, read and approved the submitted version.

\section{FUNDING}

The study was supported by grants from the Beijing Natural Science Foundation (Grant No. 7182130), the National Natural Science Foundation of China (Grant Nos. 81370898 and 81471024), the CAMS Innovation Fund for Medical Science (Grant Nos. 2016-I2M-1-002 and 2017-I2M-1-011), and the National Key Program of Clinical Science (Grant No. WBYZ2011-873).

\section{SUPPLEMENTARY MATERIAL}

The Supplementary Material for this article can be found online at: https://www.frontiersin.org/articles/10.3389/fphys. 2019.01296/full\#supplementary-material

Kersten, S. (2014). Physiological regulation of lipoprotein lipase. Biochim. Biophys. Acta 1841, 919-933. doi: 10.1016/j.bbalip.2014.03.013

Kim, M. S., Yoon, C. Y., Jang, P. G., Park, Y. J., Shin, C. S., Park, H. S., et al. (2004). The mitogenic and antiapoptotic actions of ghrelin in 3T3-L1 adipocytes. Mol. Endocrinol. 18, 2291-2301. doi: 10.1210/me.2003-2459

Kojima, M., Hosoda, H., Date, Y., Nakazato, M., Matsuo, H., and Kangawa, K. (1999). Ghrelin is a growth-hormone-releasing acylated peptide from stomach. Nature 402, 656-660. doi: 10.1038/45230

Kos, K., Harte, A. L., O’Hare, P. J., Kumar, S., and McTernan, P. G. (2009). Ghrelin and the differential regulation of des-acyl (DSG) and oct-anoyl ghrelin (OTG) in human adipose tissue (AT). Clin Endocrinol. 70, 383-389. doi: 10.1111/j. 1365-2265.2008.03321.x

Ku, H. C., Liu, H. S., Hung, P. F., Chen, C. L., Liu, H. C., Chang, H. H., et al. (2012). Green tea (-)-epigallocatechin gallate inhibits IGF-I and IGF-II stimulation of 3T3-L1 preadipocyte mitogenesis via the $67-\mathrm{kDa}$ laminin receptor, but not AMP-activated protein kinase pathway. Mol. Nutr. Food Res. 56, 580-592. doi: $10.1002 / \mathrm{mnfr} .201100438$

Lane, M. D., and Tang, Q. Q. (2005). From multipotent stem cell to adipocyte. Birth Defects Res. A Clin. Mol. Teratol. 73, 476-477. doi: 10.1002/bdra.20150

Lee, J. H., Patel, K., Tae, H. J., Lustig, A., Kim, J. W., Mattson, M. P., et al. (2014). Ghrelin augments murine T-cell proliferation by activation of the phosphatidylinositol-3-kinase, extracellular signal-regulated kinase and protein kinase C signaling pathways. FEBS Lett. 588, 4708-4719. doi: 10.1016/j.febslet. 2014.10.044

Lenhard, J. M. (2011). Lipogenic enzymes as therapeutic targets for obesity and diabetes. Curr. Pharm. Des. 17, 325-331. doi: 10.2174/13816121179516 4185

Liu, J., Lin, H., Cheng, P., Hu, X., and Lu, H. (2009). Effects of ghrelin on the proliferation and differentiation of 3T3-L1 preadipocytes. J. Huazhong Univ. Sci. Technolog. Med. Sci. 29, 227-230. doi: 10.1007/s11596-009-0218-x

Liu, P., Kong, F., Wang, J., Lu, Q., Xu, H., Qi, T., et al. (2015). Involvement of IGF1 and MEOX2 in PI3K/Akt1/2 and ERK1/2 pathways mediated proliferation and differentiation of perivascular adipocytes. Exp. Cell Res. 331, 82-96. doi: 10.1016/j.yexcr.2014.09.011

Martin, K. A., Mani, M. V., and Mani, A. (2015). New targets to treat obesity and the metabolic syndrome. Eur. J. Pharmacol. 763(Pt A), 64-74. doi: 10.1016/j. ejphar.2015.03.093

Miegueu, P., St Pierre, D., Broglio, F., and Cianflone, K. (2011). Effect of desacyl ghrelin, obestatin and related peptides on triglyceride storage, metabolism and GHSR signaling in 3T3-L1 adipocytes. J. Cell. Biochem. 112, 704-714. doi: $10.1002 /$ jcb. 22983 
Mracek, T., Drahota, Z., and Houstek, J. (2013). The function and the role of the mitochondrial glycerol-3-phosphate dehydrogenase in mammalian tissues. Biochim. Biophys. Acta 1827, 401-410. doi: 10.1016/j.bbabio.2012.11.014

Obregon, M. J. (2008). Thyroid hormone and adipocyte differentiation. Thyroid 18, 185-195. doi: 10.1089/thy.2007.0254

Pettersson, I., Muccioli, G., Granata, R., Deghenghi, R., Ghigo, E., Ohlsson, C., et al. (2002). Natural (ghrelin) and synthetic (hexarelin) GH secretagogues stimulate H9c2 cardiomyocyte cell proliferation. J. Endocrinol. 175, 201-209. doi: 10.1677/joe.0.1750201

Porteiro, B., Diaz-Ruiz, A., Martinez, G., Senra, A., Vidal, A., Serrano, M., et al. (2013). Ghrelin requires p53 to stimulate lipid storage in fat and liver. Endocrinology 154, 3671-3679. doi: 10.1210/en.2013-1176

Rauchová, H., Zacharová, G., and Soukup, T. (2004). Influence of chronically altered thyroid status on the activity of liver mitochondrial glycerol-3phosphate dehydrogenase in female inbred lewis rats. Horm. Metab. Res. 36, 286-290. doi: 10.1055/s-2004-825664

Rodriguez, A., Gomez-Ambrosi, J., Catalan, V., Gil, M. J., Becerril, S., Sainz, N., et al. (2009). Acylated and desacyl ghrelin stimulate lipid accumulation in human visceral adipocytes. Int. J. Obes. Lond. 33, 541-552. doi: 10.1038/ijo. 2009.40

Rodriguez, A., Gomez-Ambrosi, J., Catalan, V., Rotellar, F., Valenti, V., Silva, C., et al. (2012). The ghrelin O-acyltransferase-ghrelin system reduces TNF-alphainduced apoptosis and autophagy in human visceral adipocytes. Diabetologia 55, 3038-3050. doi: 10.1007/s00125-012-2671-5

Rosen, E. D., Hsu, C. H., Wang, X., Sakai, S., Freeman, M. W., Gonzalez, F. J., et al. (2002). C/EBPalpha induces adipogenesis through PPARgamma: a unified pathway. Genes Dev. 16, 22-26. doi: 10.1101/gad.948702

Smith, P. J., Wise, L. S., Berkowitz, R., Wan, C., and Rubin, C. S. (1988). Insulinlike growth factor-I is an essential regulator of the differentiation of 3T3-L1 adipocytes. J. Biol. Chem. 263, 9402-9408.

Tian, C., Zhang, L., Hu, D., and Ji, J. (2013). Ghrelin induces gastric cancer cell proliferation, migration, and invasion through GHS-R/NF-kappaB signaling pathway. Mol. Cell. Biochem. 382, 163-172. doi: 10.1007/s11010-013-1731-6

Tschop, M., Weyer, C., Tataranni, P. A., Devanarayan, V., Ravussin, E., and Heiman, M. L. (2001). Circulating ghrelin levels are decreased in human obesity. Diabetes Metab. Res. Rev. 50, 707-709. doi: 10.2337/diabetes.50.4.707
Warchol, M., Krauss, H., Wojciechowska, M., Opala, T., Pieta, B., ZukiewiczSobczak, W., et al. (2014). The role of ghrelin, leptin and insulin in foetal development. Ann. Agric. Environ. Med. 21, 349-352. doi: 10.5604/1232-1966. 1108603

Williams, D. L., Grill, H. J., Cummings, D. E., and Kaplan, J. M. (2006). Overfeeding-induced weight gain suppresses plasma ghrelin levels in rats. J. Endocrinol. Invest. 29, 863-868. doi: 10.1007/bf03349188

Wright, S. M., and Aronne, L. J. (2012). Causes of obesity. Abdom. Imaging 37, 730-732. doi: 10.1007/s00261-012-9862-x

Yan, K., Zhu, H., Xu, J., Pan, H., Li, N., Wang, L., et al. (2017). Lotus leaf aqueous extract reduces visceral fat mass and ameliorates insulin resistance in HFDinduced obese rats by regulating ppargamma2 expression. Front. Pharmacol. 8:409. doi: 10.3389/fphar.2017.00409

Ye, N., Wang, L., Dou, Z., and Huang, J. (2018). Ghrelin accelerates the cartilagic differentiation of rabbit mesenchymal stem cells through the ERK1/2 pathway. Cytotechnology 70, 415-421. doi: 10.1007/s10616-017-0156-6

Young, H. E., Mancini, M. L., Wright, R. P., Smith, J. C., Black, A. C. Jr., Reagan, C. R., et al. (1995). Mesenchymal stem cells reside within the connective tissues of many organs. Dev. Dyn. 202, 137-144. doi: 10.1002/aja.100202 0205

Zhang, W., Zhao, L., Lin, T. R., Chai, B., Fan, Y., Gantz, I., et al. (2004). Inhibition of adipogenesis by ghrelin. Mol. Biol. Cell 15, 2484-2491. doi: 10.1091/mbc.e0309-657

Zhu, H. J., Deng, J. Y., and Gong, F. Y. (2006). Primary culture of human preadipocyte in a serum-free medium. Basic Clin. Med. 7, 770-773.

Conflict of Interest: The authors declare that the research was conducted in the absence of any commercial or financial relationships that could be construed as a potential conflict of interest.

Copyright (c) 2019 Miao, Pan, Wang, Yang, Zhu and Gong. This is an open-access article distributed under the terms of the Creative Commons Attribution License (CC BY). The use, distribution or reproduction in other forums is permitted, provided the original author(s) and the copyright owner(s) are credited and that the original publication in this journal is cited, in accordance with accepted academic practice. No use, distribution or reproduction is permitted which does not comply with these terms. 